\title{
Independent-Norm Federalism in Criminal Law
}

\author{
Susan R. Klein $\uparrow$
}

\section{INTRODUCTION}

Does anyone desire constitutionally required, Supreme Court-imposed federalism in the field of criminal law? While many conservatives would respond affirmatively as quickly as liberals would decline, I suggest that a deeper exploration reveals that their actual preferences are just the opposite. The federalism conservatives say they want, which consists of striking down federal criminal statutes that duplicate state laws, accomplishes nothing. The federalism they may receive if the Court continues on its current path and enforces the doctrine neutrally ${ }^{1}$ will probably allow behavior that they find morally reprehensible. On the other hand, liberals, long in favor of rigorous federal judicial protection of individual liberties but a deferential approach to judicial review under the Commerce Clause, may be surprised to find that federalism can enhance individual autonomy and lifestyle choices well beyond what the U.S. Constitution mandates. Whether liberals or conservatives should champion federalism in criminal law ultimately depends on what we mean by "federalism," whether it can be effectively and neutrally enforced, and what kinds of state regulations such enforcement protects.

I contend that there are two distinct forms of federalism yet to be acknowledged: the "decentralization" or "fifty-labs" version, and what I call "independent-norm" federalism. The difficult issues we face are presented only by the latter. The first version of federalism seeks to preserve local

Copyright $\odot 2002$ Califomia Law Review, Inc. Califomia Law Review (CLR) is a Califomia nonprofit corporation. CLR and the authors are solely responsible for the content of their publications.

i Baker \& Botts Professor in Law, University of Texas at Austin. B.A., Wellesley College, 1984; J.D., School of Law, University of California, Berkeley (Boalt Hall), 1989. I thank Lynn Baker, Mitchell Berman, Jesse Choper, Mark Gergen, Heidi Hurd, Nancy J. King, Douglas Laycock, Michael Moore, Edward L. Rubin, Lanry Sager, John Yoo, and Ernie Young for discussions and comments on the drafts, and Cristina Ashworth and Sean Keveney for research assistance. I appreciated the opportunity to present this piece at an early stage at the University of San Diego Faculty Workshop. I greatly benefited fron the Commentary provided by Michael R. Dreeben, Dep. Solicitor General, U.S. Department of Justice, at the University of Texas School of Law Faculty Colloquia-Guest Lecture Series. Finally, I am grateful for the vision and patience of Alexander Haas, Senior Articles Editor, for this Colloquium.

1. Admittedly, two questionable assumptions. 
control of the criminal-justice system and to foster diversity and experimentation that might improve efficiency ${ }^{2}$ in areas where there is nationwide agreement as to general goals, ${ }^{3}$ though perhaps not as to the best means for achieving those goals. This form of federalism, the focus of the vast majority of scholarship and Supreme Court decisions, concerns such questions as whether the federal judiciary should permit concurrent jurisdiction over the same criminal conduct, ${ }^{4}$ whether the federal executive branch should refrain from exercising its authority to initiate charges in some categories of cases, ${ }^{5}$ and under what conditions Congress should participate in ${ }^{6}$ and distribute grants to ${ }^{7}$ innovative state law-enforcement efforts.

The second form of federalism fosters a community's expression of morality by protecting individuals from federal prosecution for generally

2. New State Ice Co. v. Leibmann, 285 U.S. 262, 3 I I (I932) (Brandeis, J., dissenting).

3. Examples of some shared general goals include the prohibition of firearms in our schools, the punishment of those who assault women, and the criminalization of arson.

4. The three most recent examples are United States v. Lopez, 514 U.S. 549, 551 (1995), invalidating the federal Gun-Free School Zones Act as violative of the Commerce Clause, United States v. Morrison, 529 U.S. 598, 601 (2000), invalidating the civil-remedy section of the federal Violence Against Women Act as violative of the Commerce Clause, and Jones v. United States, 529 U.S. $848,850(2000)$, interpreting a federal arson statute as excluding the destruction of a private residence to avoid the constitutional question of whether an alternative interpretation would have violated the Commerce Clause.

5. For example, despite the constitutionality of successive federal and state prosecutions for the same offense under the dual-sovereignty doctrine, a federal prosecution will not be initiated after a state prosecution for substantially the same conduct absent "compelling interests of federal law enforcement." Thompson v. United States, 444 U.S. 248, 248 (1980); see also U.S. ATT'Ys MANUAL $\$ 9-2.031$ (1999) (detailing current version of the Petite policy and requiring approval by the Assistant Attorney General). Additionally, federal prosecutors regnlarly decline to institute federal criminal charges altogether in favor of a state forum. U.S. ATT'YS MANUAL § 9-27.240 (1997) ("Initiating and Declining Charges-Prosecution in Another Jurisdiction") (outlining general principles to assist federal prosecutors in determining whether to decline a case in favor of a state prosecution).

6. See, e.g., Office of Juvenile Justice and Delinquency Prevention, U.S. Dep't of Justice, Promising Strategies to Reduce Gun Violence 31 (1999) [hereinafter Promising STRATEGIES] (lauding innovative joint federal-and-state programs in eight cities to reduce gun violence, which left most of the social programs and criminal prosecutions to the state actors); Daniel C. Richman, "Project Exile" and the Allocation of Federal Law Enforcement Authority, 43 ARIZ. L. REv. 369, 373 (2001) (detailing devolution of federal criminal law-enforcennent power from the U.S. Department of Justice in Washington, D.C., to the ninety-four U.S. Attorney's offices, which cooperate with state and local authorities in areas covered by concurrent federal and state criminal jurisdiction).

7. See, e.g., Public Safety Partnership and Community Policing Act, Pub. L. No. 103-322 tit. I, 108 Stat. 1807 (1994) (codified as amended at 42 U.S.C. $\$ 3796 \mathrm{dd}$ (2002)); Project Exile: The Safe Streets and Neighborhoods Act of 2001, S. 619, 107th Cong. (2001) (providing grants to state lawenforcenent agencies, prosecutors, courts, and probation officers of state conditioned on their enacting mandatory minimum sentences for the use of a firearm in any violent crime or serious drug-trafficking offense); Paul Coverdell National Forensic Sciences Improvement Act of 2000, Pub. L. No. 106-561, 114 Stat. 2787 (2000) (providing grants to improve the quality, timeliness, and credibility of forensicseience services for criminal-justice purposes); Violent Offender DNA Identification Act of 1999, S. 903, 106th Cong. (1999) (requiring Federal Bureau of Investigation to develop a voluntary plan to assist state and local forensic laboratories in performing DNA analyses on samples collected from convicted offenders). 
victimless behavior that local and state governments have determined is blameless, where there is no nationwide consensus (but rather strongly held diametrically opposed views) on the morality of the behavior. Here, the state's norm is independent of the federal norm. The issue in independentnorm federalism, largely ignored by the Court ${ }^{8}$ and commentators, ${ }^{9}$ is whether the grant of power to Congress in the Commerce Clause, as limited by the rights of the states expressed in the Tenth Amendment, allows the federal government to criminalize the conduct or otherwise inpede the state laws permitting it.

In Part I of this Essay, I explore the differences between these two forms of federalism and argne that decentralization federalism is adequately protected in the criminal-law area without Court intervention by ordinary political processes, legal doctrines, and institutional arrangements. My original contribution to the scholarship which makes this point in the civil arena ${ }^{10}$ will be to deinonstrate that federalism is especially protected in criminal law, because ordinary preemption doctrine is inapplicable, few private causes of action are available, and the federal law-enforcement apparatus is small relative to the states. Thus most, if not all, of the cominunity-based variations in enforcing crimmal proscriptions described by my colleagues in this Colloquium are not threatened by federal action to the contrary, and they need no Court protection. Where the Court insists on protecting states from duplicative criminal legislation, it may waste time and institutional capital but effect no real change. Most such federal criminal statutes are primarily symbolic "feel-good" enactınents that generally can be reenacted in a constitutional manner or instituted instead by conditional or outright grants of resources to the states. Moreover, individuals who violate previously valid federal criminal statutes can be prosecuted on the state level.

This is clearly not the case with independent-norm federalism. One way to view the concept is as the flip side of our Bill of Rights jurisprudence, under which federal courts protect citizens from state infringement

8. Though the Court has acknowledged the liberty-enhancing feature of federalism, it refers to maintaining sufficiently strong states that can defend against federal tyranny; it does not directly refer to preventing the national government from enacting morals legislation that disagrees with a minoritystate norm. See, e.g., Printz v. United States, 521 U.S. 898, 921 (1997) (noting that the separation of the federal and state sphere "is one of the Constitution's structural protections of liberty"); Gregory v. Ashcroft, 501 U.S. 452, 459 (1991) ("In the tension between federal and state power lies the promise of liberty.").

9. But see Lynn A. Baker \& Enest A. Young, Federalism and the Double Standard of Judicial Review, 51 DuKE L.J. 75 (suggesting that federalism, in fostering state-by-state diversity, may promote liberal as well as conservative conception of the social good); Barry Friedman, Valuing Federalism, 82 MnN. L. REv. 317, 401-03 (1997) (arguing that, in addition to allowing states to serve as laboratories, federalism can protect cultural and local liberty).

10. For a small sampling of the federalism scholarship making this point, see infra notes 20-23. This is not to suggest that the academic community agrees on this proposition. For a sampling of federalism scholarship disputing this point, see infra notes 24-25. 
of their constitutionally guaranteed liberties. Where Congress enacts legislation to criminalize behavior specifically protected by the state government, the Court is called upon to prevent the national government from infringing upon state-created liberty interests. ${ }^{11}$ This category of legislation criminalizes activities that the states wish to permit, and thus it directly conflicts with, rather than supplements, state norms. When only a few states are outliers, they will probably not succeed, via the national political process, in protecting their citizens from the majority's will. Unlike instances of concurrent jurisdiction, federal prosecutions in these cases will have a significant chilling effect on the behavior, well beyond the small number of cases that can actually be brought. Accordingly, for states wishing to pursue minority independent norms, it is the Court or bust.

In Part II, I outline my own agnostic position regarding whether such norm independence is desirable. It seems to me that fracturing the country in this manner has at least as many disadvantages as benefits. While doing so would protect minority lifestyles and allow individuals to maximize their conception of welfare, a glance through history and to other countries suggests that our nation may not remain cohesive if divided on basic moral issues. Moreover, a stringent Court-imposed federalism test can prevent progressive federal legislation insufficiently connected to commerce or otherwise unauthorized under Congress's constitutional powers. ${ }^{12}$ However, assuming an affirmative answer to the question of desirability, I argue that this independent-norm federalism can be fostered only by a bright-line test policed by the judicial branch. Process federalism, perhaps sufficient to protect decentralization federalism, ${ }^{13}$ will not assist with independent-norm federalism. Alternative tests suggested by scholars are insufficiently objective ${ }^{14}$ Further, I argue against a new approach, as recent Commerce Clause decisions, as well as decisions striking down legislation enacted pursuant to Section Five of the Fourteenth Amendment, are already leading us in the direction of independent-norm federalism. ${ }^{15}$ A strict requirement that the

11. Cf. Paul v. Davis, 424 U.S. 693, 710 (1976) (noting that federal civil-rights action based upon violation of procedural due process requires that government official deprive an individual of a liberty or property right previously "recognized and protected by state law"). When I say "liberty" in this context, I refer to behavior and transactions that competent adult parties engage in voluntarily; I do not refer to those liberties protected by the Bill of Rights, substantive due process, or any other constitutional clause.

12. See infra notes 123-25.

13. See infra note 208.

14. See infra notes 194-197 and accompanying text.

15. The recent Commerce Clause cases push us in this direction by adding the requirement that the effect on commerce be substantial, that the effect of the regulation be relatively direct, and that the activity regulated be a commercial one. See infra Part 11.B (discussing United States v. Lopez, 514 U.S. 549 (1995), and United States v. Morrison, 529 U.S. 598 (2000)).

Recent Section Five cases shift us toward the Commerce Clause as the primary enumerated power under which the federal government can enact legislation. They limit congressional action pursuant to Section Five of the Fourteenth Amendment to regulation of state conduct rather than private conduct. 
prohibited behavior cross state lines, or that it have a direct economicspillover effect on other states, may accomplish the goal in a manner least subject to the very real danger posed by the ideologically driven agendas of some of the Justices. ${ }^{16}$

Finally, in Part III, I explain how some recent controversies will be affected by the Court's future federalism jurisprudence where independence of norms is at issue. I will focus here on same-sex marriages, ${ }^{17}$ the socalled right to die of those suffering a terminal illness, ${ }^{18}$ and state endorsement of medicinal marijuana. ${ }^{19}$ Despite conservative intolerance of these liberties, and the federal government's attempt to control state law in each of these cases, a neutrally enforced, Court-driven federalism doctrine could protect these rights from federal criminalization. Such state-sanctioned activity will have mimimal direct economic impacts on neighboring states, and state residents can engage in regulated behavior without crossing a state boundary. The purpose of federal proscriptions of such conduct will likely be the protection of morality rather than regulation of the national or local economy. If "our federalism" does indeed protect state-regulated liberties from federal encroachment via the Commerce Clause, our current conservative federal legislative- and executive-branch officials are due for some surprising interactions with our equally conservative Supreme Court.

\section{Federalism in Criminal LaW}

One primary controversy reflected in the scholarship and in the recent series of five-to-four U.S. Supreme Court decisions concerns the issue of

and they require that the remedy for the actual constitutional violation be proportional to the scope of the violation. See id. (discussing City of Boerne v. Flores, 521 U.S. 507 (I997), and Board of Trustees of the University of Alabama v. Garrett, 531 U.S. 356 (2001)).

16. See, e.g., Bush v. Gore, 531 U.S. 98,103 (2000) (holding, by a majority of five conservative Justices, that the Equal Protection Clause prohibits the state of Florida from recounting votes pursuant to state law); Frank B. Cross \& Emerson H. Tiller, The Three Faces of Federalism: An Empirical Assessment of Supreme Court Federalism Jurisprudence, 73 S. CAL. L. Rev. 741, 762 (2000) (identifying ideology as the dominant determinant of the Court's federalism decisions).

17. In response to Baehr v. Lewin, 852 P.2d 44 (Haw. 1993), a decision by the Hawaii Supreme Court finding that a statute providing that only opposite-sex couples could marry violated the state's Equal Protection Clause, Congress passed the Defense of Marriage Act, 28 U.S.C. $§ 1738$ (c) (1996) (enacted), which provides that no state is required to accord full faith and credit to a same-sex marriage that is valid in the state in which the marriage was performed.

18. Despite the Death with Dignity Act passed by Oregon voters, Attorney General Ashcroft has instructed Drug Enforcement Administration agents to revoke the drug licenses of physicians in Oregon who help patients to commit suicide. See Dispensing of Controlled Substances to Assist Suicide, 66 Fed. Reg. 56,607 (Nov. 6, 2001) (to be codified at 21 C.F.R. pt. 1306).

19. Since the Supreme Court's nuling in United States v. Oakland Cannabis Buyers' Cooperative, 532 U.S. 483,486 (2001), that there is no common-law medical-necessity defense to federal criminal prosecution of drug users, the Department of Justice under Ashcroft has begun raiding medicalmarijuana clubs in California. Greg Winter, U.S. Cracks Down on Medical Marijuana in California, N.Y. TMES, Oct. 31, 2001, at A12. 
whether the political process sufficiently protects state power from federal usurpation absent Court intervention. One argument, originating with Professor Wechsler in $1954,{ }^{20}$ advanced by Dean Choper in $1980,{ }^{21}$ and adopted briefly by the Court in $1985,{ }^{22}$ states that the formal constitutional structure of American politics, along with informal political institutions such as our major political parties, ${ }^{23}$ offers states such considerable protections from federal legislative overreaching that judicial review is unnecessary. The opposing arguments suggest that the failure of political safeguards, coupled with the constitutional mandate of a federal government of enumerated powers, requires active judicial policing of federal legislation to protect the states. ${ }^{24}$ Legislators, though elected from each state, may too quickly become members of the federal government seeking to

20. Herbert Wechsler, The Political Safeguards of Federalism: The Role of the States in the Composition and Selcction of the National Government, 54 CoLUM. L. REv. 543 (1954) (arguing that structural features of the U.S. Constitution, such as equal state representation in the Senate and the role of the states in selecting the President through the electoral college, justify the Court's inattention to federalism).

21. Jesse H. Choper, Judicial Review and the National Political Process (1980) (urging that the Court should conserve its political capital for individual-rights cases and treat issues of federalism as nonjusticiable and emphasizing practical political restrains on national power, such as congressional delegations' bipartisan pursuit of state interests, the President's political need to maintain a relationship with Congress, the fact that most federal elected officials began as state officeholders, and mechanisms such as bicameralism, the committee system, the Presidential veto, and the filibuster that allow minorities to block legislation); see also Bradford R. Clark, Separation of Powers as a Safeguard of Federalism, 79 TEx. L. Rev. 1321, 1324-25 (2001) (suggesting that a strict approach to the separation-of-powers and Supremacy Clause doctrines will safeguard the states); Lino A. Graglia, United States v. Lopez: Judicial Review Under the Commerce Clause, 74 TEx. L. REv.719, 720 (1996) (suggesting that the Court should explicitly withdraw from federalism review to "cease facilitating the growth of national power" and contribute to "honesty in constitutional law").

22. Garcia v. San Antonio Metro. Transit Auth., 469 U.S. 528, 531 (1985) (holding that the concept of "traditional governmental function" was incoherent, and reversing National League of Cities v. Usery, 426 U.S. 833 (1976)). As Professor Yoo has noted, the Court has since tacitly overruled Garcia. John C. Yoo, The Judicial Safeguards of Federalism, 70 S. CAL. L. REv. 1311, 1334-57 (1997).

23. Larry D. Kramer, Putting the Politics Back into the Political Safeguards of Federalism, 100 Colum. L. REv. 215, 276 (2000); Larry D. Kramer, Understanding Federalism, 47 VAND. L. Rev. 1485,1523 (1994) (arguing that political parties protect state authority by "linking the fortunes of officeholders at state and federal levels, fostering a mutual dependency that protects state institutions by inducing federal lawmakers to take account of (at least some) desires of state officials").

24. See, e.g., Jenna Bednar \& William N. Eskridge, Jr., Steadying the Court's "Unsteady Path": A Theory of Judicial Enforcement of Federalism, 68 S. CAL. L. Rev. 1447, 1450 (1995) (arguing that the "best" reading of the Supreme Court's federalism jurisprudence is that the judiciary has reasserted itself as a monitor to remind Congress to operate within its constitutional limits); Steven G. Calabresi, "A Government of Limited and Enumerated Powers": In Defense of United States v. Lopez, 94 MICH. L. REv. 752 (1995) (hailing Lopez as a "revolutionary and long overdue" revival of the concept that the federal government possesses limited and enumerated powers); Marci A. Hamilton, Why Federalism Must be Enforced: A Response to Professor Kramer, 46 ViLl. L. REv. 1069, 1071 (2001) (arguing that Larry Kramer's theory fails both as a matter of constitutional history and on empirical grounds); Saikrishna B. Prakash \& John C. Yoo, The Puzzling Persistence of Process-Based Federalism Theories, 79 TEx. L. Rev. 1459, 1460 (2001) (positing that conceiving of the political process as the exclusive protection of federalism is inconsistent with the Constitution's text, structure, and original understanding). 
grab more power from the states. ${ }^{25}$ A resolution, or even a full debate, of this argument as applied to the criminal-law field is hobbled by two failures: first, a failure to separately analyze federal crimmal statutes depending upon whether they duplicate or oppose state norms; second, a failure to note important distinctions between institutions and legal doctrines in civil and criminal law. I will decouple decentralization from independent-norm federalism in Part I.A, then federalism in the civil arena from federalism in criminal law in Part I.B below.

\section{A. Decentralization Federalism in Criminal Law}

One prevalent view of federalism focuses on the twin goals of preserving local control in fields traditionally left to state governments and developing better laws and procedures through experimentation in the fifty states. ${ }^{26}$ If such decentralization is the goal of federalism in criminal law, then this goal is naturally achieved through existing legal doctrines and institutions, without judicial review of federal criminal legislation, at least in those instances where federal and state actors share the same basic moral framework. Scholars and the Court fail to distinguish between instances where state and federal governments agree on the behavior to be proscribed (resulting in concurrent jurisdiction over the same criminal conduct), and instances where the governments disagree (resulting in federal jurisdiction that criminalizes behavior protected by state norms). Despite the spate of recent Court cases and scholarship "protecting" states from these federal criminal statutes, states need no Court protection where criminal jurisdiction over agreed-upon misconduct is concurrent because they either do not intend to experiment in a way radically different from the method employed by federal government, or they can happily experiment in a manner consistent with federal legislation. Where all state and federal officials agree as to the impropriety of the underlying conduct, state officials' failure to prevent such federal legislation is not due to lack of political ability,

25. William W. Van Alstyne, The Second Death of Federalism, 83 Mich. L. REv. 1709, 1712 (1985); John C. Yoo, Sounds of Sovereignty: Defining Federalism in the 1990s, 32 IND. L. REv. 27, 39 (1998). As aptly pointed out by Frank Cross, however, the Article III judges deciding federalism disputes "are, like legislators, typically "members of the federal government" with the saine "human concerns for "power, prestige, and glory"' as congressmen. Frank B. Cross, Realism About Federalism, 74 N.Y.U. L. REV. 1304, 1315 (1999).

26. See, e.g., New State Ice Co. v. Leibmann, 285 U.S. 262 (1932); Jesse Choper, The Scope of National Power Vis-à-Vis the States: The Dispensability of Judicial Review, 86 YALE L.J. 1552, 1614 (1977) (writing that the purpose of federalism is "to promote the efficiency of government administration"); Michael C. Dorf \& Charles F. Sabel, A Constitution of Democratic Experimentalism, 98 CoLUM. L. REv. 267 (1998) (suggesting that decentralization advances the goal of federalism: an "experimentalist collaboration between the states and the federal government"); H. Geoffrey Moulton, Jr., The Quixotic Search for a Judicially Enforceable Federalism, 83 MiNN. L. Rev. 849, 852 (1999) ("The great insight of federalism is that different levels of government have different competencies, and that wisely allocating responsibilities to those different levels of government can work significant benefits in terms of both citizen satisfaction and governmental efficiency."). 
but rather to their apathy (or as we say in Texas, they have no dog in that fight). Some examples will illustrate both that the majority of statutes and cases concern concurrent jurisdiction and not independent norms, and that the states either sought federal assistance or were indifferent to it.

Every criminal case reviewed by the Court for consistency with the Commerce Clause, with the significant exception of the criminal enforcement of New Deal legislation, ${ }^{27}$ involved instances of concurrent jurisdiction where the states were in favor of the federal law in question. For example, in a series of cases from 1903 to 1925, the Court sustained criminal laws prohibiting the interstate transportation of lottery tickets, ${ }^{28}$ the transportation across state lines of women to be used for immoral purposes, ${ }^{29}$ and the interstate transportation of stolen vehicles. ${ }^{30}$ These activities were already prohibited by the states. ${ }^{31}$ Likewise, in a series of cases from the 1950s to the 1970s where the Supreme Court upheld the federal criminalization of the movement of items and persons across state lines, such as the travel by a person in aid of the commission of a state crime $e^{32}$ and the possession by a convicted felon of a firearm that had moved across state lines, ${ }^{33}$ and sustained the federal criminal regulation of intrastate

27. Federal criminal enforcement of the New Deal legislation was in opposition to state norms and was stricken by the Court before the switch in time that saved nine. See, e.g., United States v. Wrightwood Dairy Co., 315 U.S. 110 (1942) (sustaining federal law controlling price of milk for sale); United States v. Darby, 312 U.S. 100 (1941) (finding that a federal prohibition of interstate lumber shipments produced im states that violated wage-and-hour standards, established by the Fair Labor Act of 1938, was an unconstitutional violation of congressional power under the Commerce Clause). However, those cases do not fit into my category of independent state norms that will or should be protected by the Court's new Commerce Clause jurisprudence. Those cases involved quintessentially commercial activity. See infra Part 11.B.

28. The Lottery Case (Champion v. Ames), 188 U.S. 321, 354 (1903) (upholding the constitutionality of the Federal Anti-Lottery Act of 1895, as within Congress's plenary power to regulate interstate commerce).

29. Caminetti v. United States, 242 U.S. 470, 492 (1917) (upholding the Mann Act by finding that Congress possessed the authority to keep the channels of interstate commerce free from immoral and injurious use).

30. Brooks v. United States, 267 U.S. 432, 436 (1925) (holding that the National Motor Vehicle Theft Act of 1919 was a constitutional exercise of Congress's power to punish the use of such commerce to promote immorality).

31. See, e.g., Robert E. Cushman, The National Police Powers under the Commerce Clause of the Constitution, 3 MiNN. L. REv. 289, 383-92 (1919) (noting that in 1895, Congress responded to national disapproval of lotteries by prohibiting the movement of lottery tickets by mail or via interstate commerce).

32. Perrin v. United States, 444 U.S. 37, 41 n.5 (1979) (upholding Travel Act conviction based on commercial bribery under New York law, where the requisite interstate nexus is present by way of "phone calls from Louisiana to Richmond, Texas, by Willis and Levy, and the subsequent shipment of materials by the Richmond firm to Louisiana by Continental Bus"); Rewis v. United States, 401 U.S. 808,812 (1971) (reversing a conviction under the Travel Act in which there was no evidence that the defendant "had employed interstate facilities to conduct his numbers operation; moreover he could not readily identify which customers had crossed state lines," Perrin, 444 U.S. at 49 (discussing Rewis)).

33. United States v. Bass, 404 U.S. 336, 337-38 (1971) (holding that the Omnibus Crime Control and Safe Streets Act of 1968 required the government to demonstrate the nexus between the possession of a firearm and interstate commerce). 
economic activity that substantially affected commerce, such as loan sharking, ${ }^{34}$ extortion and robbery, ${ }^{35}$ and gambling, ${ }^{36}$ all of the states had already enacted similar prohibitions. ${ }^{37}$ None of these represented independent state norms that state officials were unable to protect from federal encroachment.

More recent cases tell the same story. Despite the lack of protest from any state, im United States v. Lopez, the Court struck 18 U.S.C. $\$ 922(\mathrm{q})$, which prohibited the knowing possession of a firearm im a school zone, as violative of the Commerce Clause..$^{38}$ As Justice Kennedy noted in his concurrence, forty states had enacted crimmal laws prohibiting the possession of firearms on or near school grounds. ${ }^{39}$ The majority responded by asserting that "when Congress criminalizes conduct already denounced as criminal by the states, it effects a "change in the sensitive relations between federal and state criminal jurisdiction." 40 The majority's one example quoted the government's brief: “ $\$ 922$ (q) 'displaces state policy choices in ... that its prohibitions apply even in States that have chosen not to outlaw the conduct in question." "'41 However, a failure at the state level to separately criminalize gun possessions near schools cannot rationally be equated with approval of such conduct, or even with a desire by those states to prevent federal prosecutions. Before leaping to the conclusion that states approve of students' bringing guns to school, the Court would have to determine whether the conduct was prohibited by a more general criminal proscription, a school rule, or a civil or regulatory bar. Had a state enacted a provision affirmatively exempting such gun possession from

34. Perez v. United States, 402 U.S. 146, 154-55 (1971) (upholding the Consumer Credit Protection Act as a constitutional exercise of Congress's power under the Commerce Clause because extortionate credit transactions support national organized crime and allow the unregulated market to obtain control of legitimate business, thus affecting interstate and foreign commerce).

35. Stirone v. United States, 361 U.S. 212 (1960) (upholding Hobbs Act as appropriate exercise of congressional power); United States v. Green, 350 U.S. 415, 420-21 (1956) (same).

36. United States v. Five Gambling Devices, 346 U.S. 441, 451-52 (1953) (affirming the dismissal of indictments under the Act of January 2,1951, which prohibited the interstate shipnent of gambling devices, because the government failed to allege that the gambling devices at any tinie had been transported or had affected interstate commerce).

37. For a sample of states that outlawed extortion during this time, see CAL. PENAL CODE $\$ 518$ (West 1872); Conn. Gen. Stat. § 53(a)-119(5) (1969); D.C. Code ANN. § 22-2307 (1968); Fla. StaT. ch. 71.136, § 1021 (1971); N.J. Stat. ANN. \$2C: 20-2 (West 1978); N.Y. Penal Law \$ 155.05 (McKinney 1965); and Tex. PENAL CODE ANN. § 31.02 (Vernon 1973). For a sample of states that criminalized gambling during this time, see CaL. PeNal. CODE $\$ 330$ (West 1872); ConN. GEN. Stat. § 73-455 (1973); D.C. CODE ANN. § 22-1501 (1901); DEL. CODE ANN. tit. 11, § 1401 (1953); FlA. STAT. ch. 71.136, § 1059 (1971); GA. CODE ANN. § 26-2702 (Harrison 1933); N.J. STAT. ANN. § 2C: 37-1 (West 1978); N.Y. Penal Law § 222.05 (McKinney 1965); and Tex. Penal Code ANN. $\$ 47.02$ (Vernon 1973). For a sample of states that outlawed loan sharking during this time, see CoNN. GeN. STAT. 239-1 (1971) and N.J. STAT. ANN. \$2C: 21-19 (West 1978).

38. United States v. Lopez, 514 U.S. 549 (1995).

39. Id. at 582 .

40. Id. at 561 n.3 (citing Brief for United States at 29 n.18).

41. Id. 
criminal proscription or other sanctions (or been willing to state for the Court on the record that it desired that students bring guns to class), we would have a clear independent-norm problem warranting Court attention. ${ }^{42}$

This same unnecessary Court protection of the states occurred in the two most recent federalism cases. As noted by Justice Souter in his Morrison dissent, thirty-six states and the Commonwealth of Puerto Rico filed amicus briefs that supported a rape victim's use of the civil section of the Violence Against Women Act ("VAWA"), and the Court's majority position means that "the States will be forced to enjoy the new federalism whether they want it or not." ${ }^{23}$ Likewise, in Jones v. United States, the Court rejected the Department of Justice's construction of the federal arson statute as applicable to private residences, ${ }^{44}$ even though virtually every state criminalizes exactly that conduct. ${ }^{45}$

The Court accomplishes little when it intervenes to protect the states from duplicative federal legislation. As I demonstrate in Part I.B, concurrent jurisdiction does not impinge upon local experimentation as to the means to accomplish shared crime-prevention goals. Additionally, in cases of federal-state consensus, Congress can easily circumvent this unnecessary Court protection by conditioning federal spending. A seven-member majority in South Dakota v. Dole allowed Congress to condition the receipt of federal highway funds on states' raising their drinking age to twenty-one years. ${ }^{46}$ The Court held that Congress is empowered to condition such federal funds so long as they are "directly related" to the purpose of the congressional program, do not induce the state to engage in unconstitutional acts, and are not coercive. ${ }^{47}$ As my colleague Lynn Baker astutely pointed out, "the Court offered Congress a seemingly easy end run around any restrictions the Constitution might impose on its ability to regulate the states." ${ }^{48}$ Millions of federal dollars go to state law enforcement each year. ${ }^{49}$ Even under Justice O'Connor's narrower spending-power test, ${ }^{50}$

42. See infra Part II.A.

43. United States v. Morrison, 529 U.S. 598, 654 (2000) (Souter, J., dissenting). One state did oppose the federal statute, but that state also already outlawed the conduct in question.

44. Jones v. United States, 529 U.S. 848, 850-5I (2000).

45. See, e.g., IND. CoDE $\S \S 35-43-1-1,35-50-2-5$ (I993).

46. 483 U.S. 203, 206 (I987) (affirming that the conditioning of federal highway funds on statelaw drinking-age minimums is a permissible exercise of congressional spending power).

47. Id. at $210-11$.

48. Lynn Baker, Conditional Federal Spending after Lopez, 95 Colum. L. REv. 1911, 1914 (1995).

49. For example, according to the most recent Department of Justice report on the Office of Justice Programs, the Department of Justice appropriated \$3,569 million dollars in fiscal year 2000 to assist tribal and state law-enforcement efforts, \$104 million for drug courts and substance-abuse programs at the state level, and $\$ 786$ million for state crime-prevention programs. U.S. DEPARTMENT of Justice Fiscal 2000 Performance Report-Fiscal Year 2002 Performance Plan, 7, 37, 50 (2000). 
requiring that the condition effectuate the purposes of Congress's grant, there is little doubt as to the constitutionality of such largesse. ${ }^{51}$

When the state and the federal governments share the same view on the norm underlying a criminal prohibition subject to concurrent jurisdiction, though they may disagree as to the details, the punishment, or the means best suited to implement the norm, the states should be relatively easy to bribe with conditional grants of funding. On the other hand, where a state has strongly expressed an independent norm, it may choose to forgo federal money rather than capitulate. ${ }^{52}$ Moreover, when the independent norm is a noneconomic one, the state may more easily establish that the federally funded program is unrelated to the condition..$^{53}$

An alternative method for circumventing Court-imposed decentralization federalism, which will be effective in the vast majority of cases, is for Congress to simply rewrite the stricken statute by adding the jurisdictional hook of interstate movement. This is precisely what Congress did in the wake of the Court's Lopez decision to strike down the Gun-Free School Zones Act, by amending 18 U.S.C. $\$ 922(q)$ to require that the individual possess "a firearm that has moved in or that otherwise effects interstate or foreign commerce. ${ }^{" 54}$ Congress was smart enough to add this jurisdictional

50. South Dakota v. Dole, 483 U.S. 203, 216 (1987) (O'Connor, J., dissenting).

51. This is true today, but the Court has shown little regard lately for federalism precedent. Conservatives are presently pushing these cases, and the Supreme Court of Washington recently struck down a Spending Clause statute. See, e.g., Guillen v. Pierce County, 31 P.3d 628, 650-51 (Wash. 2001) (holding that 28 U.S.C. $\$ 409$, which makes traffic and accident materials nondiscoverable in state and local courts, violates the Spending Clause), cert. granted, 122 S. Ct. 1788 (2002); Ilya Somin, Closing the Pandora's Box of Federalism: The Case for Judicial Restriction of Federal Subsidies to State Governments, 90 GEO. L.J. 461 (2002).

52. See Elizabeth Garrett, Enhancing the Political Safeguards of Federalism? The Unfunded Mandates Reform Act of 1995, 45 U. KaN. L. REv. 1113, $1140 \mathrm{n} .98$ (1997) (noting case of Virginia's and New Hampshire's partial refusal of conditional federal education funding under the Goals 2000 program). Contrast this with the fate of Louisiana's minimum drinking age of eighteen. In 1984, Congress passed the National Minimum Drinking Age Act ("NMDAA") in the hopes of establishing a uniform drinking age and eliminating the ability of young persons to drive across state lines in search of more lenient jurisdictions. See 23 U.S.C. $\$ 158(2000)$ (providing that $10 \%$ of apportioned highway funds will be withheld from states in which "the purchase or public possession in such a state of any alcoholic beverage by a person who is less than twenty-one years of age is lawful"). In response to the NMDAA, Louisiana first passed meaningless legislation that established the drinking age as twentyone, but it provided no penalties for vendors who sold alcohol to minors. Act No. 33, 1987 La. Acts. 2746. After considerable federal pressure and facing the prospect of deteriorating highways, Louisiana acquiesced and closed the loophole in 1995 by criminalizing the sale of alcohol to minors. Act No. 639, 1995 La. Acts 1674.

53. See, e.g., United States v. Sabri, 183 F. Supp. 2d 1145 (D. Minn. 2002) (holding that application of 18 U.S.C. $\$ 666$ (2000) (pertaining to federal-program bribery) to local corruption unconnected to the federally funded program violated Dole's requirement of a connection between the federal interest and the federal regulation); United States v. McCormack, 31 F. Supp. 2d 176, 188 (D. Mass. 1998) (same).

54. H.R. 3610, Pub. L. No. 104-208, 110 Stat. 3009 (codified at 18 U.S.C. $\$ 922(q)(2)(a)(2000)$ ). Though the statute now permits the prosecutor to prove either interstate movement or an effect on commerce, I argue, infra Part II.B, that only proof of interstate movement will save the statute from the 
hook in advance to the criminal section of the VAWA. ${ }^{55}$ The majority in Morrison, while striking down the civil provision without the jurisdictional hook, noted approvingly that the Courts of Appeals had uniformly upheld this criminal provision as fitting squarely within the "channels" category. ${ }^{36}$ Though Congress caunot circumvent all Commerce Clause review via a jurisdictional hook, it will be much easier to do so with economically motivated criminal legislation, where travel across state boundaries is more likely, and much harder to do so with morals legislation, where travel is less likely. This is precisely why, as I will argue below, Court protection is sensible only in the latter instance.

This Court-imposed decentralization federalism not only fails to protect the states qua states, but also fails to protect individual liberties. By definition, in cases of concurrent criminal jurisdiction, the state can prosecute the person who violated the norm if the federal statute is struck down on Commerce Clause grounds. ${ }^{57}$ Though a state can choose not to prosecute an individual at the state level, if it shares the federal norm and criminalizes the same behavior, then state prosecution seens likely. Thus using judicial review to supplement the political process in protecting states qua states and in protecting states as guarantors of individual liberties is generally a waste of time.

\section{B. Civil-Criminal Federalism Distinctions}

In addition to their failure to distinguish decentralization from independent-norm federalism, scholars and the Court have failed to recognize features particular to criminal law that impact federalism principles. Two aspects of criminal law further militate against Court intervention in instances of concurrent jurisdiction. First, federal criminal statutes do not preempt state law in the field; second, federal criminal statutes cannot be enforced by private causes of action. These two factors, combined with institutional considerations, protect the decentralization goal of federalism without assistance from the Court.

I will begin with preemption. Where constitutionally enacted federal and state criminal laws do not directly and clearly conflict, and hence there is no Supremacy Clause issue, ordinary preemption doctrine will not displace the state laws. This is quite unlike what we have recently come to

additional requirements that the regulated activity substantially affect commerce, that it be a commercial activity, and that such effect not be overly attenuated.

55. 18 U.S.C. $\$ 2261$ (a)(1) makes it a crime to travel across a state line to injure or harass an intimate partner or to do so in the course of or as a result of such travel.

56. United States v. Morrison, 529 U.S. 598, 612 n.5 (2000).

57. For example, Mr. Lopez already had been arrested and charged under Texas law with firearm possession on school premises before the United States Attorney's office decided to prosecute. See United States v. Lopez, 514 U.S. 549, 551 (1995) (describing original charge under TeXas PENal CODE ANN. § 46.03(a)(1) (Supp. 1994)). 
expect in civil cases, where the Court regularly uses preemption to displace entire bodies of state regulations and state-created private causes of action. For example, in Buckman Co. v. Plaintiff Legal Comm., the Court dismissed state-law fraud claims against a manufacturer's regulatory consultant as impliedly preempted by the federal Food, Drug, and Cosmetic Act. ${ }^{58}$ The Court has also recently struck down state regulation of business via the preemption doctrine in cases in which states attempt to permit suits for business torts, ensure safe business practices, and require safe products and services. ${ }^{59}$ The Court's newfound commitment to federalism apparently does not extend to protecting consumers from big business, even where the state government desires this protection. ${ }^{60}$ Thus, in the civil arena, without Court-imposed Commerce Clause restrictions on federal legislation, such legislation might preempt entire fields from state regulation.

On the other hand, where federal criminal laws regulate conduct already regulated by the states, such federal legislation does not displace the state criminal-justice system, but rather supplements it with concurrent jurisdiction. Though a single Supreme Court case in 1956 held that a nonregulatory federal crimmal statute preempted state criminal legislation, ${ }^{61}$ the Supreme Court has not stricken a state crimmal statute on

58. 531 U.S. 341,344 (2001).

59. See, e.g., Lorillard Tobacco Co. v. Reilly, 533 U.S. 525, 553 (2001) (ruling that Massachusetts advertising regulations targeting cigarettes were preempted by the Federal Cigarette Labeling and Advertising Act); Crosby v. Nat'l Foreign Trade Council, 530 U.S. 363, 372 (2000) (striking down a Massachusetts state law prohibiting state contracts with the Burmese government because it was an obstacle to Congress's objectives under the federal Foreign Operations, Export Financing, and Related Programs Appropriations Act); Geier v. Honda Motor Co., 529 U.S. \$61, 865 (2000) (holding that the petitioners' suit under state tort law conflicted with Federal Motor Vehicle Safety Standard 208 and was preempted because the state claims would be an obstacle to the regulatory scheme); United States v. Locke, 529 U.S. 89, 94 (2000) (finding that Washington state's regulation of oil-vessel navigation and safety was preempted by a comprehensive federal regulatory scheme); AT\&T Corp. v. Iowa Utils. Bd., 525 U.S. 366 (1999) (holding that the 1996 Telecommunications Act divested the states of their regulatory authority over local telephone markets in favor of central rule making by the Federal Communications Commission); Am. Airlines, Inc. v. Wolens, 513 U.S. 219 (1995) (holding that the preemption prescription of the Airline Deregulation Act barred state regulation of air carriers); Morales v. Trans World Airlines, 504 U.S. 374, 391 (1992) (ruling that the Americans with Disabilities Act preempted suits against air carriers under state consumer-protection laws); Ingersoll-Rand Co. v. McClendon, 498 U.S. 133, 138-39 (1990) (finding that the Employee Retirement Income Security Act of 1974 preempted state common-law claims for unlawful discharge related to pension plans).

60. For a gentle critique of the Court's preemption doctrine on federalism grounds, see Ernest A. Young, Two Cheers for Process Federalism, 46 VILL. L. REv. 1349, 1377-84 (2001). For a scathing review, see Cross \& Tiller, supra note 16, at 753-54 (finding "selective invocation" of federalism in the preemption decisions).

61. Pennsylvania v. Nelson, 350 U.S. 497, 504 (1956) (holding that the federal Smith Act, prohibiting knowing advocacy of the overthrow of the U.S. govermment by force or violence, preempted the Pennsylvania sedition act, which prohibited the same conduct, noting that the federal government had specifically urged local authorities not to intervene). In two earlier cases, the Court found that state statutes did not impinge on the federal offense of counterfeiting or on the raising of armies for the national defense. See Gilbert v. Minnesota, 254 U.S. 325 (1920); Fox v. Ohio, 46 U.S. (5 How.) 410 (1847). 
preemption grounds for nearly half a century. ${ }^{62}$ Conventional wisdom tells us that "in the criminal context there is a clear understanding that Congress ordinarily intends to supplement state law, rather than to regulate coinprehensively and occupy the field," ${ }^{63}$ and lower courts have routinely rejected claims regarding the preemptive effects of federal criminal statutes. ${ }^{64} \mathrm{~A}$ refusal to apply preemption doctrine in the criminal-law area allows the vast majority of criminal cases to continue to be brought in the state systems, without the necessity of Court intervention via the Commerce Clause and regardless of the passage of federal legislation.

An even more significant limit on federal encroachment of state criminal law-enforcement authority is the exceedingly few private causes of action available to enforce criminal law. ${ }^{65}$ When Congress passes a civil statute, such as the provision struck down in Morrison, neither federal nor state governments control the number or quality of actions brought pursuant to the statute. On the other hand, only an Assistant U.S. Attorney or a trial attorney with the Department of Justice can bring an action to enforce a criminal provision of a federal code. This severely limits the impact of federal criminal statutes on state criminal-justice regimes. The federal government cannot increase its percentage of the total federal and state criminal-law caseload without a politically intolerable increase in the federal income tax. Since the 1930s, only five to ten percent of criminal felony cases brought each year are filed in federal court ${ }^{66}$ Though there is great

62. In Jones v. United States, Justice Stevens argued that the "presumption against federal preemption of state law" dictated interpreting the federal statute to apply only to arsons of businesses, as otherwise the federal criminal statute, which authorizes a sentence of thirty-five years, would displace the state "policy choice" to punish home arson with a ten-year maximum. Jones v. United States, 529 U.S. 848, 859 (2000) (Stevens, J., with Thomas, J., concurring). The implication here is that a clear statement by Congress that 18 U.S.C. $\S 844$ (1998) applies to arsons of private residences would mean that the federal arson statute would preempt the Indiana state statute. This is strange, given that every federal criminal statute displaces state policy choices unless the federal and state statutes are identical in punishment and procedure, yet the Court has not held that any of these federal criminal statutes preempt state criminal statutes.

63. Norman Abrams \& Sara S. Beale, Federal Criminal Law and Its Enforcement 681 (3d ed. 2000).

64. See, e.g., Pic-A-State PA, Inc. v. Pennsylvania, 42 F.3d 175, 176 (3d Cir. 1994) (holding that state statute criminalizing the sale within one state of another state's lottery ticket was not precluded by 18 U.S.C. $\$ 1301$ (1988), which criminalizes conducting a business that sells another state's lottery tickets); United States v. Ruthstein, 414 F.2d 1079, 1083 (7th Cir. 1969) (finding that Congress has not preempted the states "from proscribing the transmission of gambling information").

65. These include civil RICO claims, 18 U.S.C. $\$ 1962$ (2000), and qui tam actions to enforce fraud, 31 U.S.C. $\$ 3730(b)(1)(2000)$.

66. ABRAMS \& BEALE, supra note 63, at 13 (noting that in 1998 there were almost one million felony filings in the fifty states versus about 35,000 in federal district court); see also Tom Stacy \& Kim Dayton, The Underfederalization of Crime, 6 CORNell J.L. \& PUB. POL'Y 247, 249-50 (1997) ("The image of a runaway national government increasingly taking away the enforcement of the criminal law from the States is essentially false. The available evidence indicates that the national government's share in the enforcement of criminal law has been actually been diminishing for more than the last half century."). 
controversy regarding the propriety of the "federalization" of criminal law, commentators agree that this resource allocation means that the federal government will continue to be a minor player in criminal-law enforcement. The practical debate is whether the broad discretion this federalization gives to prosecutors in selecting which cases to bring is better limited by the Court, Congress, or the Department of Justice. ${ }^{67}$

This severe resource limitation, ${ }^{68}$ coupled with the fact that individuals bringing a private cause of action are monetarily rewarded, whereas the federal government is monetarily penalized ${ }^{69}$ by bringing federal criminal actions and paying for incarceration, means that the threat of federal encroachment on state criminal-justice systems is small. Not only will the total percentage of federal criminal-law actions per state criminal-law filings remain small, but most of these federal prosecutions will continue to be filed in the same few areas-immigration violations, interstate and international drug offenses, and complex white-collar offenses. ${ }^{70}$ Absent the unlikely possibility of drug decriminalization, the small percentage left over for discretionary use will move around to make symbolic strikes with no real effects. ${ }^{71}$

67. Those arguing in favor of limits by the Department of Justice include Rory K. Little, Myths and Principles of Federalization, 46 Hastings L.J. 1029, 1081-82 (1995); Dan M. Kahan, Is Chevron Relevant to Federal Criminal Law?, 110 HaRv. L. Rev. 469, 486-87 (1996) (suggesting that the Court defer to the Department of Justice's interpretation of federal criminal statutes); Michael A. Simons, Prosecutorial Discretion and Prosecution Guidelines: A Case Study in Controlling Federalization, 75 N.Y.U. L. REv. 893,899 (2000) (suggesting that Department of Justice guidelines on federal prosecutions adequately controls prosecutorial discretion).

Those advocating Court or congressional limitations on prosecutorial discretion include Franklin E. Zimring \& Gordon Hawkins, Toward a Principled Basis for Federal Criminal Legislation, 543 ANNALS 15, 16-17 (1996), and Kathleen F. Brickey, Criminal Mischief: The Federalization of American Criminal Law, 46 HASTINGS L.J. 1135, 1136 (1995).

68. As of 1999, there were fewer than 12,000 Federal Bureau of lnvestigation special agents, 4,500 Drug Enforcement Administration agents, 9,000 U.S. Customs Service agents, 2,000 Alcohol, Tobacco and Firearms agents, and 500 Assistant U.S. Attorneys in the 94 U.S. Attorney Offices located throughout the country, compared to the close to 700,000 police officers and 30,000 state and local prosecutors nationwide. ABRAMS \& BEALE, supra note 63, at 6-13.

69. An exception to this is criminal forfeiture brought in the money laundering, drug, and RICO areas. 18 U.S.C. $\$ 982$ (2002); 21 U.S.C. $\$ 853$ (2002); 18 U.S.C. $\$ 1963$ (2002).

70. These categories account for almost $80 \%$ of the criminal caseload. U.S. SENTENCING COMM'N, SOURCEBOOK OF FEDERAL SENTENCING Statistics (1996), available at http://www.ussc.gov/linktojp.htm (noting that in 1998 slightly over $40 \%$ of federal offenders were convicted of drug-related offenses; almost $20 \%$ were for white-collar offenses, and almost $16 \%$ were immigration offenses).

The federal government's latest war on "fill in the blank" will certainly change, as the Department of Justice declared a war on organized crime in the early 1950s, a war on white-collar crime in the mid1970 s, a war on official corruption in the late 1970s, a war on drugs began in earnest in the 1980s, a war against violent crime in the $1990 \mathrm{~s}$, and, of course, our current war on international terrorism. See generally Nancy E. Marion, A History of Federal Crime Control Initiatives, 1960-1993 (1994).

71. See, e.g., Sara Sun Beale, Too Many and Yet Too Few: New Principles to Define the Proper Limits for Federal Criminal Jurisdiction, 46 Hastings L.J. 979, 981 (1995) ("When Congress has chosen to legislate by adding new federal crimes, it has neither preempted state law as a formal matter 
Consider Lopez once again. There was no good reason for the U.S. Attorney's office to initiate the case, as the defendant had already been indicted at the state level, and this was not a statute to which any U.S. Attorney's office would ordinarily devote any resources. Although the U.S. Attorney initially refused to take the case, there was a push from the Department of Justice to prosecute at least some cases under the statute. A press conference was held with the U.S. Attorney and Senator Gramm announcing the "get tough" policy on guns in schools. In the view of Richard Durbin, the Assistant U.S. Attorney assigned to the case, this move was solely political; society would have been better off with a felony conviction in state court than a misdemeanor conviction in federal court. ${ }^{72} \mathrm{Mr}$. Durbin further informed me that his office had not prosecuted another school-zone case since Lopez, and he did not intend to. His reticence is not related to the risk of a new Commerce Clause challenge under the revised statute; these cases simply are not worth the time and money spent on thein. ${ }^{73}$ For these reasons, only a handful of reported cases have been brought under this statute, pre- and post-Lopez, nationwide. ${ }^{74}$

As a result of these peculiar attributes of criminal law-that federal criminal statutes do not preempt state ones, that there are few private federal criminal causes of action, and that the federal law-enforcement apparatus is small relative to states'-the so-called federalization of criminal law has not stopped the local experimentation that characterizes decentralization federalism. Because 90 to $95 \%$ of felony offenders are prosecuted in state rather than federal criminal-justice systems, local experimentation as to the method of achieving shared federal and state law-enforcement goals has flourished. The fact that occasionally a felon is diverted from the state to the federal system has little if any impact on these state experiments.

nor provided sufficient resources to supplant state enforcement as a practical matter."); Task Force on the Federalization of Criminal Law, The Federalization of Criminal Law 1998 A.B.A. SEc. Crim. Just. L. REP. 51, 53 (noting that the "new waves of federal statutes often stand only as symbolic book prohibitions with few actual prosecutions").

72. The federal penalty for violating 18 U.S.C. $\S 922(q)$ is a fine, not more than five years imprisonment, or both, though "for the purposes of any other law a violation of section 922(q) shall be deemed to be a misdemeanor." 18 U.S.C. $§ 924(a)(4)$ (2000). Mr. Lopez was sentenced to six months imprisonment. United States v. Lopez, 514 U.S. 549, 550 (1995). The state charge that was dismissed against Mr. Lopez, Tex. Penal Code ANN. $\S 46.03$ (a)(1) (Vernon 1994), is a third-degree felony. See TEx. Penal Code ANN. $\$ 46.03$ (g) (Vernon 1994). A third-degree felony is punishable under Texas law by two to ten years in prison. Tex. Penal Code ANN. $\$ 12.34$ (Vernon 1994).

73. Telephone Interview with Richard Durbin, Assistant U.S. Attorney for the Western District of Texas (Aug. 5, 2001) (notes on file with author).

74. 1 found only eight reported cases: United States v. Lopez, 514 U.S. 549 (1995); United States v. Walker, 59 F.3d 1196 (11th Cir. 1995); United States v. Edwards, 55 F.3d 428 (9th Cir. 1995); United States v. Knowles, 29 F.3d 947 (5th Cir. 1994); United States v. Daniels, 874 F. Supp. 1255 (N.D. Ala. 1995); United States v. Morrow, 834 F. Supp. 364 (N.D. Ala. 1993); United States v. Ornelas, 841 F. Supp. 1087 (D. Colo. 1994); United States v. Holland, 841 F. Supp. 143 (E.D. Pa. 1993). 
There are plenty of data points left for determining whether the particular state method is effective. ${ }^{75}$

Current examples of state experiments run the gamut from boot camps, ${ }^{76}$ drug courts, ${ }^{77}$ and shaming devices ${ }^{78}$ to community policing ${ }^{79}$ and civil commitment for sexually violent predators. ${ }^{80}$ The assertion by Justice Kennedy in his Lopez concurrence that "[t]he statute now before us forecloses the States from experimenting and exercising their own judgment in [the] area"s1 lacks empirical foundation and is false. He claims that the Gun-Free School Zone Act will eliminate better alternatives, such as

inducements to inform on violators where the information leads to arrests or confiscation of the guns,... programs to encourage the voluntary surrender of guns with some provision for amnesty, ... penalties imposed on parents or guardians for failure to supervise the child,... laws providing for suspension or expulsion of gun-toting students, ... or programs for expulsion with assignment to special facilities. ${ }^{82}$

In footnotes, he reveals that all of those programs are in force in various states. ${ }^{83}$ Because the vast majority of violators will be prosecuted in state courts, social scientists can continue to do the empirical studies necessary to determine the effectiveness of these means of achieving gun-free schools. State and federal policymakers will naturally gravitate toward those methods.

Finally, decentralization federalism needs no Court protection to protect experimentation because federal authority already tends to devolve downward

75. This is obviously true for most federal statutes that replicate state crimes-the chance of being pulled into federal rather than state court is like a bolt of lightning striking. Even when there is a substantial number of federal prosecutions, as in the controlled substance area, there are still plenty of defendants left over for state experiments.

76. Shay Bilchik, Office of Juvenile Justice and Delinguency Prevention, U.S. Dep'T of Justice, Program Report: Juvenile Justice Reform Initiatives in the States, 1994-95 (1997), available at http://www.ojjdp.ncjrs.org/pubs/reform (detailing the rise between 1983 and 1995 of adult boot camps in over thirty states and juvenile boot camps in ten states).

77. In 1997, the U.S. General Accounting Office found that there were 162 drug courts operating in thirty-eight states, the District of Columbia and Puerto Rico. U.S. Gen. Accounting Office, Drug Courts: Overview of Growth, Characteristics, and Results, GAO/GGD-97-106 (July 31, 1997) (report to the Senate Committee on the Judiciary and the House Committee on the Judiciary).

78. See Stephen P. Garvey, Can Shaming Punishments Educate?, 65 U. CHI. L. Rev. 733, 734-35 (1998) (discussing cases).

79. See, e.g., George L. Kelling \& William J. Bratton, Declining Crime Rates: Insiders' Views of the New York City Story, 88 J. CRIM. L. \& CRIMINOLOGY 1217, 1218-19 (1998).

80. Nancy J. King \& Susan R. Klein, Essential Elements, 54 VAND. L. Rev. 1467, 1491 (2001) (providing a list of states enacting civil commitment of sexual offender statutes in the wake of Kansas v. Hendricks, 521 U.S. 346 (1997), where the Court upheld the civil commitment of sexual predators against ex post facto and double-jeopardy challenges).

81. United States v. Lopez, 514 U.S. 549, 583 (1995) (Kennedy, J., concurring).

82. Id. at 582 .

83. Id. (listing state statutes). 
from the Department of Justice in Washington, D.C. ("main Justice"), to the ninety-four local U.S. Attorney's offices throughout the country, to state and local task forces. The structure of the federal law-enforcement apparatus encourages such devolution. Though the public understands the U.S. Attorneys and their assistants to work for the Attorney General, this is not actually the case. U.S. Attorneys, like the Attorney General, are appointed by the President, and, depending on their personal relationship with the President, may wield more authority than the Attorney General herself. ${ }^{84}$ Moreover, these U.S. Attorneys are customarily selected by senators from their home states. Thus, they are politically beholden to the state senator, rather than to the President, and their ties are to their state as well as to the Beltway. ${ }^{85}$ Though technically there are certain cases that U.S. Attorney's offices may not initiate absent main Justice approval, that rule is honored "most often in the breach." $\$ 6$

Many commentators, politicians, and scholars have noted the decentralization of federal law-enforcement authority. ${ }^{87}$ Examples, such as the federal government's law-enforcement responses to illegal gun use and ownership, abound. The Eastern District of Virginia's U.S. Attorney's office and the Norfolk, Virginia, District Attorney's office responded with "Operation Exile," which has been touted equally by the Democratic and Republican administrations. ${ }^{88}$ This project, which funnels only certain gun arrests made by state and local authorities into federal court, and is combined with a community-outreach-and-education initiative and a media

84. That was certainly the case for Attorney General Janet Reno, former President Clinton's third choice.

85. James Eisenstein, Counsel for the United States: U.S. Attorneys in the Political AND LEGAL SySTEMS 116 (1978) (noting that a U.S. Attorney's ties to senators and local political figures who submitted his name for appointment gave him a sense of independence from Washington).

86. The quote comes from former Department of Justice official Charles F.C. Ruff, in Charles F.C. Ruff, Federal Prosecution of Local Corruption: A Case Study in the Making of Law Enforcement Policy, 65 Geo. L.J. 1171, 1207-08 (1977). See also Richard S. Frase, The Decision to File Federal Criminal Charges: A Quantitative Study of Prosecutorial Discretion, 47 U. CH. L. REv. 246, 250 n.16 (1980) (discussing the range of responses by U.S. Attorney's offices to requirements by main Justice of consultation before proceeding). My own experience working some money laundering and narcotics cases out of the U.S. Attorney's office in San Diego, on detail in 1993-94 from main Justice, was that there was a general disdain for taking "orders" from officials at main Justice who had less experience than the line attorneys and less familiarity with local customs and requirements.

87. See, e.g., EISENSTEIN, supra note 85, at 209-10 (noting that decentralization allows branch offices to bring cases against high-level political figures that potential political pressure would prevent main Justice from bringing); Kahan, supra note 67, at 497 (lamenting decentralization and "the incentives that individual U.S. Attomeys have to bend the law to serve purely local interests").

88. Former Democratic Attorney General Janet Reno praised the program during her congressional testimony. Hearing Before the Committee on the Judiciary United States Senate Concerning Justice Department Oversight, 106th Cong. (1999) (statement of Janet Reno, U.S. Att'y Gen.), available at http://www.usdoj.gov/archive/ag/testimony/1999/agjudic050599.htm; see also R.H. Melton, Bush Favors Va.-Style Gun Control; Candidate Has National Hopes for Program Penalizing Felons, WASH. Post, June 23, 1999, at A8 (stating that former Governor George W. Bush was calling for the implementation of Project Exile nationwide). 
campaign, is effective because cooperation and intelligence are provided by local authorities. ${ }^{89}$ While this response may work well in Virginia, the U.S. Attorney im Boston prefers "Operation Cease Fire," which uses probation and gang-unit officers to target youth gangs, order-maintenance tactics to suppress flare-ups, intensive inspections of federal firearm licensees, and provides at-risk youth with social services, job training, and conflictresolution training. ${ }^{90}$ The U.S. Attorney in the Southern District of New York prefers "Federal Day," a once-a-month program that shunts violators of concurrent federal and state criminal proscriptions to federal rather than state court. ${ }^{91}$ The U.S. Attorney in Maryland and her state counterparts developed "Project DISARM," shared, the federal government seems content and perhaps even eager to refrain from interfering with the fifty labs conducting crime-control experimentation on the state level. To these fifty labs, we can add another innety-four loci of experimentation reflected in the different approaches adopted in the various U.S. Attorney's Offices.

On a more abstract level, my argument for the deferential review of federal criminal statutes that duplicate state norms is a variant of processbased federalism. The administrative state contains certain safeguards that protect decentralization federalism ${ }^{94}$ but not independent-norm federalism.

89. See generally Richman, supra note 6, at 373 (detailing Project Exile as one example of "a new stage in the devolution of federal enforcement power"); Daniel C. Richman, The Changing Boundaries Between Federal and Local Law Enforcement, in 2 CRIM. JUST. 2000: BouNDARY Changes in Criminal Justice Organizations 94 (Julie E. Samuels ed., Nat'l Inst. of Justice, 2000) (noting that main Justice understands that the necessary cooperation of state and local officials with its antiviolence initiatives could he achieved only through arrangements that U.S. Attorneys negotiate district by district).

90. See Promising Strategies, supra note 6 (outlining the "Boston Strategy" and profiling joint federal-and-state programs to reduce gun violence in seven other cities).

91. Stephen Labaton, New Tactics in the War on Drugs Tilts Scales of Justice Off Balance, N.Y. Times, Dec. 29, 1989, at Al.

92. See Promising STRATEgies, supra note 6, at 142 (describing the strategy by U.S. Attorney Lynne A. Battaglia, which declined to charge every drug offender eligible for federal prosecution, instead took an approach based on a collaborative federal and state case-referral and screening process).

93. Professor Richman's insight is that Congress has in fact specifically organized the federal enforcement bureaucracy in a manner that promotes decentralization out of concern for presidential power. See Daniel C. Richman, Federal Criminal Law, Congressional Delegation, and Enforcement Discretion, 46 UCLA L. REv. 757 (1999) (arguing that Congress curbs the federalization of criminal law not through legislative specificity in its substantive lawmaking, but rather through structural and procedural mechanisms of control such as that control over appointments, hearings, agency budgets and structure, and limitations on investigations).

94. Though there may be little negative effect on states qua states from this federalization, there are two significant negative effects on individual liberties: the potential for an individual to suffer successive federal and state prosecutions for the same criminal conduct, Bartkus v. People of State of Ill., 359 U.S. 121, 138 (1959), and the availability of differing procedures and penalties in state and federal prosecutions for the same crimes, United States v. Armstrong, 517 U.S. 456, 479 (1996) (Stevens, J., dissenting) (noting that a guilty verdict for defendant in federal court provided a mandatory life term, whereas in state court his sentence could have been as short as six years). Much scholarship bemoans the federalization of criminal law precisely for these reasons, my own work 
The facts that the Department of Justice has few resources relative to states, that it and other federal law-enforcement agencies are organized in the field along state lines, and that the Court does not preempt state legislation in the criminal-law field all lead to less need for Court diligence in cases of concurrent jurisdiction. These are long-standing institutional features that are highly unlikely to change.

\section{Independent-Norm Federalism in Criminal Law}

The institutions, legal doctrines, and political processes that protect the states from federal encroachment when moral values are shared are ineffective in protecting what I have called independent-norm federalism in criminal law. When the state's norm is independent of the federal norm, the outlier state will rarely obtain the allies necessary to win protection from contrary federal legislation in the political process. The lack of federal preemption and private causes of action will likewise fail to protect citizens in outlier states from federal prosecution where the federal norm differs. One older and one more recent example concerning issues of sexuality, and one controlled-substance example where the state minority was substantial, will demonstrate this point.

The first example demonstrating this lack of protection is the federal response to Mormon polygamy in the late nineteenth century. In a series of statutes culminating in 1887 , Congress criminalized polygamous marriages in Utah through prohibitions against bigamy and cohabitation. ${ }^{95}$ The purpose of these federal criminal statutes, as evidenced by the legislative history and Supreme Court interpretation, was to eradicate the independent

included. See, e.g., Steve D. Clymer, Unequal Justice: The Federalization of Criminal Law, $70 \mathrm{~S}$. CAL. L. Rev. 643, 646 (1997); Susan R. Klein, Double Jeopardy's Demise, 88 CALIF. L. Rev. 1001, 1002 (2000).

Some of the successive state and federal prosecution problems are prevented by the Department of Justice's Petite Policy. See U.S. ATT'ys MANUAL, supra note 5, § 9-2.031. The number of such successive prosecutions is only, by the most generous count, in the low 100s. Sandra Guerra, The Myth of Dual Sovereignty: Multijurisdictional Drug Low Enforcement and Double Jeopardy, 73 N.C. L. REv. 1160, 1208 n.245 (1995) (finding over 100 cases since 1975). Likewise, the Department of Justice has attempted to curb forum shopping by encouraging federal prosecutors to decline bringing federal charges altogether in favor of a state forum in appropriate circumstances. See supra note 5 . While I do not mean to minimize these problems, it does seem that banning all concurrent jurisdiction in the criminal-law area is an overbroad reaction, and that federalism doctrine is not the right tool for the job. A more targeted response would be to renounce the dual-sovereignty doctrine and to provide a more lenient selective-prosecution claim.

95. Congress passed the Morrill Act criminalizing bigamy as a felony in 1862. Morrill Act, ch. 125, § 1, 12 Stat. 501 (1862) (codified at U.S. Rev. Stat. $\$ 5352$ ). In 1874, Congress passed the Poland Act, facilitating polygamy convictions by transferring cases from the Mormon-controlled probate courts to the non-Mormon federal system. Poland Act, ch. 469, 13 Stat. 253 (1874). Finally, Congress passed the Edmunds Act, criminalizing bigamy, polygamy, or unlawful cohabitation, in 1882 . Edmunds Act, ch. 47, 22 Stat. 30 (1882) (codified at 48 U.S.C. $\$ 1461$ (1882) (repealed 1983)); Edmunds Tucker Act of 1887, ch. 397, 24 Stat. 635 (1887) (codified at 28 U.S.C. $\$ \S 633,660$ (1887) (repealed 1978)). 
norm practiced in Utah. ${ }^{96}$ Though Congress enacted these statutes pursuant to the explicit text of the Property Clause ${ }^{97}$ and not the Commerce Clause, and one could argue that the outcome might have been different had Utah been a state at the time this war against polygamy began, historical evidence undermines such an argument. These federal criminal statutes passed by huge margims, ${ }^{98}$ despite the fact that they not only criminalized polygamy, but procedurally impinged upon the First, Fifth, Fourth, and Sixth Amendment rights of the Mormons. ${ }^{99}$ The perceived immorality of the practice would have overshadowed the desire of other states to take up Utah's cause in the interest of states' rights.

More recently, Congress in 1996 enacted the Defense of Marriage Act ("DOMA"), federally defining marriage as exclusively heterosexual and authorizing individual states to refuse to give full faith and credit to same-sex marriages performed in other states. ${ }^{100}$ As one commentator noted, the debates over DOMA mirrored the morality play of the debates over the antipolygamy statutes. ${ }^{101}$ They included debates over whether bisexuals could have legal harems, whether a state could prohibit marriage to

96. For a full discussion of the history of Mormon polygamy, see Mary K. Campbell, Mr. Peay's Horses: The Federal Response to Mormon Polygamy, 1854-1887, 13 Yale J.L. \& Feminism 29 (2001). See also Cannon v. United States, 116 U.S. 55, 72 (1885) (upholding cohabitation conviction under the Edmunds Act, despite lack of evidence of living or sleeping together, as the statute seeks not to punish sex with multiple women but rather "to prevent a man from flaunting in the face of the world the ostentation and opportunities of a bigamist household..."); Reynolds v. United States, 98 U.S. 145, 166 (1878) (upholding the Morrill Act against a Free Exercise Clause challenge in part because "polygamy leads to the patriarchal principle, and ... applied to large communities, fetters the people in stationary despotism, while that principle cannot long exist in connection with monogamy"); 47 CoNG. REC. 13,1156 (1882) (remarks of Senator Sherman of Ohio) (suggesting criminal prohibition was "the only remedy for this evil"); $i d$. at 1158 (remarks of Senator Garland) (noting that "desperate cases need desperate remedies").

97. U.S. CONST. art. IV, $\$ 3$, cl. 2.

98. See, e.g., Cong. Globe, 36th Cong., 1st Sess. 1519 (1860) (statement of Representative Thayer) (noting during discussion of the Morrill Bill that "every member from every section of the Union is ready to assert the odious criminality of polygamy. It is encouraging, it is refreshing, to know that there is at least one subject on which there is no sectionalism"); EDwIN BRowN FIRMAGE \& Richard Collin Mangrum, Zion in the Courts: A Legal History of the Church of Jesus CHRIST OF LATTER-DAY SAINTS, I830-1900, at 166 (1988) (noting that after passing the Senate, the Edmunds Act cleared the House 199 to 42, with 51 not voting).

99. For example, the Morrill Act revoked the statute incorporating the Mormon Church, prohibited any religious organization from holding real estate worth more than $\$ 50,000$, and required that all future holding above the statutory amount escheat to the federal government; the Edmunds Act created a five-man commission to oversee elections in Utah, disallowed current or past polygamists the vote, and allowed prosecutors to strike a potential juror for cause if he had been practicing polygamy, refused to answer a question about his marital status, or simply believed it was right for a man to have more than one wife. The forfeiture of existing property was upheld in Late Corp. of the Church of Jesus Clrist of Latter-Day Saints v. United States, 136 U.S. 1 (1890); the denial of the vote based on a test oath that excluded any believing Mormon was upheld in Davis v. Beason, 133 U.S. 333 (1890). These cases held such despite the fact that at the time congressional actions concerning citizens in the territory were restricted by the Bill of Rights.

100. Pub. L. No. 104-199, §2(a), 110 Stat. 2419 (codified at 28 U.S.C. $\$ 1738$ (c) (2000)).

101. David L. Chambers, Polygamy and Same-Sex Marriage, 26 Hofstra L. REv. 53 (1997). 
children, and whether marriage could be limited to human beings. ${ }^{102}$ One southern congressman asked: "If a person had an 'insatiable desire' to marry more than one wife, ... what argument did gay activists have to deny him a legal, polygamous marriage?"103 Like the antipolygamy criminal statutes, DOMA passed both houses of Congress by huge margins, ${ }^{104}$ despite questions as to its constitutionality under the Equal Protection and Full Faith and Credit Clauses. ${ }^{105}$ The few outlier states that might have opposed such legislation, such as Hawaii and Vermont, did not stand a chance of winning this national debate.

A final example of the failure of the political process to protect independent minority norms is the inability of a large minority of states (currently tallied at nine) to convince their colleagues in Congress to either reschedule marijuana from a Schedule I to a Schedule II or III substance, or to allow an exemption for medicinal use by the seriously ill. In 1986, the Drug Enforcement Administration ("DEA") held two years of formal hearings on the possible rescheduling of marijuana. Although an administrative-law judge ruled that marijuana did have a "currently accepted medical use"106 and recommended moving it from Schedule I to Schedule II, the administrator of the DEA rejected his findings. ${ }^{107}$ In March of 1992, the Food and Drug Administration eliminated its Individual Use Investigation New Drug Program, which had given a small number of patients marijuana on a limited basis. ${ }^{108}$ In 1998, Congress passed the "Sense of the Congress"

102. Defense of Marriage Act: Hearing on Sen. 1740 Before the Senate Comm. on the Judiciary, 104th Cong. (1996), available at 1996 WL 387295 (statement of Rep. Largent); see also 142 CoNG. REC. H7443 (daily ed. July 11, 1996) (statement of Rep. Largent).

103. See Andrew Sullivan, Three's a Crowd, New Republic, June 17, 1996, at 10 (quoting question asked of him by Congressman Bob Engles of South Carolina during hearings).

104. 142 CoNG. REC. H7505-06 (daily ed. July 12, 1996) (the Bill passed the House by a vote of 342 to 67 ); 142 CoNG. Rec. S.10129 (daily ed. Sept. 10, 1996) (the Bill passed the Senate by a vote of 85 to 14$)$.

105. See, e.g., Andrew Koppelman, Dumb and DOMA: Why the Defense of Marriage Act Is Unconstitutional, 83 Iowa L. REv. I (1997) (arguing that DOMA violates the Equal Protection Clause because it impermissibly discriminates and was enacted with an invidious motive); Julie L.B. Johnson, Comment, The Meaning of "General Laws": The Extent of Congress's Power under the Full Faith and Credit Clause and the Constitutionality of the Defense of Marriage Act, 145 U. PA. L. REv, 1611, 1613-15 (1997) (arguing that Congress had no authority under the Full Faith and Credit Clause to enact DOMA).

106. Alliance for Cannabis Therapeutics v. Drug Enforcement Admin., 930 F.2d 936, 938 (D.C. Cir. 1991). The Court upheld the DEA's rejection of the judge's ruling in Alliance for Cannabis Therapeutics v. Drug Enforcement Administration, 15 F.3d 1131, 1137 (D.C. Cir. 1994).

107. A history of the states' failure to get marijuana rescheduled can be found in Lauryn P. Gouldin, Controlled Substance Law, Cannabis, Compassionate Use and the Commerce Clause: Why Developments in California May Limit the Constitutional Reach of the Federal Drug Laws, 1999 ANN. SURv. Am. L. 471, 479-483 (1999); see also Lester Grinspoon \& James B. BaKalar, Marihuana, THE FORBIDDEN MEDICINE (1993).

108. See Grinspoon \& BaKala, supra note 107, at 21-23; Sheryl Gay Stolberg, For a Very Few Patients, U.S. Provides Free Marijuana, N.Y. Times, Mar. 19, 1999, at A10; U.S. Rescinds Approval of Marijuana as Therapy, N.Y. TiMEs, Mar. 11, 1992, at A21. 
Resolution, entitled Not Legalizing Marijuana for Medicinal Use, which declared that "Congress continues to support the existing Federal legal process for determining the safety and efficacy of drugs and opposes efforts to circumvent this process by legalizing marijuana."109 Finally, in 2001 , the DEA again denied a petition to transfer marijuana from Schedule I control. ${ }^{110}$ Until either a majority of states see the value $\mathrm{m}$ medicinal marijuana or we modify our present stance on the use of controlled substances, the outlier states will never succeed in protecting their norm.

The failure to distinguish independent-norm federalism from decentralization federalism has led some scholars in favor of Court-protected federalism to suggest a single stringent standard of judicial review for all cases, criminal and civil and independent-norm and concurrent jurisdiction alike. For example, Professor Yoo suggests that there is a "false dichotomy" between the protection of individual rights and the protection of states' rights, ${ }^{111}$ and Professors Baker and Young suggest that federalism should be categorized with "individual rights that receive vigorous protection" of judicial review. ${ }^{112}$ While I would not go so far as Professor Choper in arguing that the political process is the exclusive safeguard for federalism, it seems to me that a rational-basis review is sufficient for decentralization federalism. The Court ought to reserve its current, more stringent "rational-basis-plus" inquiry ${ }^{113}$ for independent-norm federalism, just as it reserves heightened scrutiny under the Equal Protection Clause for discrete and insular minorities. ${ }^{114}$

Professor Yoo's analogy between a state's representation in Congress and an individual's representation in the national government through their elected officials, and his suggestion that both categories receive similar judicial review, is misguided as a matter of common sense, history, and constitutional text. Common sense tells us that states have a common interest in preventing federal encroachment, and there is ordinarily no reason for some states to gang up against others. Our tragic history has shown this to be anything but true im our treatment of certain minority individuals,

109. 112 Stat. $2681-760$ to -761 .

110. "Medical" Marijuana, Federal Drug Law and the Constitution's Supremacy Clause: Hearing before the Subcomm. on Criminal Justice, Drug Policy and Human Resources of the Committee on Government Reform, 107th Cong. 58-64 (2001), available at 2001 WL 2006520 (statement of Laura M. Nagel, Deputy Assistant Adm'r, Office of Diversion Control, Drug Enforcement Admin.).

111. See Prakash \& Yoo, supra note 24 , at 1476.

112. Baker \& Young, supra note 9, at 79.

113. Justice Stevens, in his dissent in Lopez, correctly noted that the Court is abandoning the rational basis test for regulation justified under the substantial-effects prong of Commerce Clause analysis. United States v. Lopez, 514 U.S. 549, 608 (1995) (Stevens, J., dissenting) ("There is today, however, a backward glance at both the old pitfalls, as the Court treats deference under the rationality rule as subject to gradation according to the commercial or noncommercial nature of the immediate subject of the challenged regulation.").

114. United States v. Carolene Prods. Co., 304 U.S. 144, 152 n.4 (1938). 
particularly in the majority's treatment of African Americans, women, homosexuals, and those accused of criminal offenses. Finally, the language in the first eight amendments of the Bill of Rights offers specific and detailed civil and criminal protections to individuals, whereas the text of the Tenth Amendment offers no protection to states or individuals beyond what remains after Congress asserts its enumerated powers. ${ }^{115}$

Professors Choper and Rubin would claim that my argument in favor of a rational-basis-plus test for state minority norms is likewise misguided, since a state being sanctioned for choosing to pursue a minority norm is unlike an individual being sanctioned for an immutable characteristic. I disagree: a state could become the federalist counterpart to an African American in Equal Protection doctrine by vigorously pursuing minority norms. In this posture, it warrants judicial protection, particularly if one believes that one of the values underlying federalism is the protection of liberty-enhancing state practices from federal interference. At the very least, the Court should apply the same rational-basis-plus test it uses to strike federal statutes that duplicate state norms to strike federal statutes that contradict state norms.

Not only does the political process fail to protect independent-norm federalism in criminal law, but particular criminal-law institutions and doctrines, such as limited federal resources, lack of preemption doctrine, and the absence of private causes of action, will not protect state experimentation with different norms the way they protect state experimentation with different means. When there is concurrent jurisdiction, the criminal, if caught, knows that he likely will face prosecution on some level. Because most cases are brought on the state level, state programs to prevent such behavior by means other than the federal program have an opportunity to fiourish. Assuming that most people choose to obey the law whether they agree with it or not, when a state chooses to pursue an independent moral norm and makes that choice clear to its citizens, by either enacting legislation to protect the norm or enshrining the norm in its constitution, some citizens will engage in this behavior. If this same behavior is criminalized federally, however, the behavior will be chilled. ${ }^{116}$ Even though federal resources for criminal prosecutions are small, the mere threat of a federal prosecution will stop all but the most hardy from engaging in this behavior, notwithstanding its legality on the state level. ${ }^{117}$

115. U.S. CoNST. amend. X (reserving "power not delegated to the United States" to the states and the people).

116. See, e.g., Ernest Van Den Haag, The Criminal Law as a Threat System, 73 J. Crum. L. \& CRIMINologY 769 (1982); Robert E. Scott, The Legal Construction of Norms: The Limits of Behavioral Theories of Law and Social Norms, 86 VA. L. REv. 1603 (2000).

117. This threat of federal criminal prosecution will successfully prevent experimentation with an independent norm despite the possibility of jury nullification. The spectre of nullification is no doubt why main Justice brought the cannabis case in San Francisco as a civil injunctive action tried to a 


\section{II}

\section{COURT-Protected Minority NoRmS}

Even if I have failed to convince the reader that the political process protects decentralization federalisin, this does not detract from my second point-the political process fails to protect independent-norm federalism. If we wish to protect such federalisin, it requires a judicially imposed solution. I will begin by discussing of the advantages and the drawbacks of such judicial protection. Next, I will offer my version of current Section Five and Commerce Clause jurisprudence. While I am not necessarily a cheerleader for present law, the Court's new limits may protect minority norms in a way previously impossible, and a better test seems unlikely.

\section{A. The Identification and Desirability of Independent-Norm Federalism}

A doctrine that protects independent-norm federalism first requires the ability to categorize federal crimmal statutes into those that supplement state regulations and those that oppose state norms. Critics may doubt the possibility of drawing such distinctions. One response would be to admit the truth of this criticism and to apply more stringent judicial review to all federal statutes that encroach upon states' prerogatives in criminal law. Aside from the waste in judicial capital, there is no lasting harm to this, as appropriate federal legislation can simply be redrafted to comport with the stricter Commerce Clause test or transformed into a conditional spending program. However, this criticism goes too far; while some cases at the margin will be difficult to categorize, most cases will not be. Generally, criminal laws are passed for a single reason-prevention of behavior identified as "bad." Preventing the behavior is the end and the method of prevention is the means. Criminalizing fraud, violent crime, and drug use are ends, employing mandatory mimimum sentences, probation, and drug courts are means. Where the ends are shared among federal and state officials, federal statutes in the area affect decentralization federalism; where the ends are not shared, federal statutes in the area impinge on mdependent state norms.

Some means to an end, however, may be considered so immoral that inflicting them upon an uncooperative state may impinge upon that state's moral norms as much as any substantive criminal law would. For example, suppose Massachusetts considers the death penalty not only morally wrong 
but also unconstitutional pursuant to its state constitution. ${ }^{118}$ Is the application of a federal statute in a federal district court in Boston permitting the death penalty for drug kingpins who foreseeably cause death $^{119}$ an allowable means to reach the shared end of ridding our country of illicit drugs, or does it violate an independent norm? Since resolving such a debate seems difficult, and since the number of such cases appears small, my solution would be to classify a regulation according to its characterization by the particular state. In other words, if a particular state found what might be characterized as a means to be sufficiently important to enact state legislation protecting or prohibiting such means, the federal court would likewise treat it as a moral norm and categorize any federal incursions as implicating independent-norm federalism. The Court could give standing to object to a federal statute as violative of a state norm only to the state itself rather than to a criminal defendant, and the problem resolves itself. ${ }^{120}$ This is, in essence, what has occurred in two of the examples I discuss in Part III: the state of Oregon objected to (and sued) the federal government to protect its right-to-die statute, and a number of District Attorneys in California have threatened to open marijuana dispensaries. ${ }^{121}$ The Court could consider the federal criminal statute an impingement upon independent-norm federalism, applying rational-basis-plus scrutiny, only if the state supports the defendant's objection to the federal statute. ${ }^{122}$

A second criticism of my categorization is that it assumes that we as a society want to protect independent-norm federalism. However, historically, federalism has been no friend of liberal society. For example, the southern states championed federalism as a method of maintaining apartheid following the Civil War, ${ }^{123}$ and states used federalism to deny

118. Commonwealth v. Colon-Cruz, 470 N.E.2d 116, 124-30 (Mass. 1984) (striking certain key procedural provisions of the Massachusetts death-penalty statute on the grounds that they impermissibly burden a constitutional right and violate Article XII of the Declaration of Rights of the Massachusetts Constitution).

I19. 21 U.S.C. $\$ 848$ (2002).

120. This also resolves the problem of a state changing its "nind" regarding a norm it formerly shared with the federaI government. The state attorney can attack a federal criminal prohibition at any time. This procedure does not harm the defendant; it is only where her state protects the norm that she will benefit from attacking the federal prohibition, as she will then be safe from state prosecution as well.

I21. See infra notes $226 \& 239$.

122. I am not suggesting strict scrutiny here, or even that the Court explicitly recognize that whether an independent state norm is at risk should be a separate factor in the Lopez analysis. Rather, I am suggesting only that the Court seriously consider any such challenges, perhaps reserving the rational-basis-plus test employed in Lopez for independent-norm rather than concurrent-jurisdiction cases.

I23. See, e.g., Akhil Reed Amar, Of Sovereignty and Federalism, 96 YALE L.J. 1425 (1987) ("Victims of government-sponsored lawlessness have come to dread the word 'federalism."); Cross, supra note 25, at 1306 ("Federalism's role in American history as a stalking horse for racism is infamous."); Edward L. Rubin, Puppy Federalism and the Blessings of America, 574 ANnals 37, 47 (2001) (chastising scholars for forgetting the southern states' treatment of Blacks after the Civil War, 
women the right to vote until and even after the passage of the Nineteenth Amendment. ${ }^{124}$ More recent is the well-documented association of federalism with the Court's assault on the New Deal. ${ }^{125}$ Given this history, it is not unreasonable to expect the continued use of federalism to prevent progressive federal legislation or to protect morally unattractive state practices.

I do not discount this danger. Still, the worst state excesses would probably be protected by the Constitution outside of Commerce Clause legislation. Certainly in the period following the New Deal, the Court became much more protective of those individual liberties enshrined in the Bill of Rights, though it is gradually becoming less protective again. ${ }^{126}$ Even where purely private conduct is at issue, such as the private discrimination outlawed in the Civil Rights Act, ${ }^{127}$ when the conduct involves bars on travel or engagement im commerce, it could still be effectively regulated federally under a stringent Commerce Clause test.

On the other hand, there are liberal advantages to allowing minority norms to flourish. The potential for the state rather than the federal government to protect individual rights in the criminal-procedure area was famously noted by Justice Brennan in $1977 .{ }^{128}$ This potential has since been realized as the Burger and Rehnquist Courts chipped away at the Warren Court revolution. Many state supreme courts continue to provide the protection originally granted by the Warren Court pursuant to the states' constitutions. ${ }^{129}$ Other advantages include fostering democracy by allowing

and noting that "we can enjoy the idea of federalism because we have forgotten the grave problems associate with its actuality").

124. Riva B. Seigel, She the People: The Nineteenth Amendment, Sex Equality, Federalism, and the Family, 115 HARv. L. REv. 947 (2002) (detailing the use of federalism in the late nineteenth century to oppose suffrage culminating in the challenge, in Leser v. Garnett, 258 U.S. 130 (1922), to the constitutionality of the Nineteenth Amendment securing the vote for women).

125. Erwin Chemerinsky, Rehabilitating Federalism, 92 MicH. L. Rev. 1333, 1333-34 (1994) (noting that federalism was invoked in the effort to frustrate New Deal reforms such as child-labor and minimum-wage legislation).

126. See the gradual incorporation of most of the Bill of Rights into the Fourteenth Amendment, and the Warren Court revolution. Wayne R. LaFave et al., Criminal Procedure, \$§ 2.1-2.6 (2d ed., 1999).

127. Heart of Atlanta Motel, Inc. v. United States, 379 U.S. 241 (1964).

128. William J. Brennan, Jr., State Constitutions and the Protection of Individual Rights, 90 Harv. L. REv. 489, 491 (1977) (urging state courts to regard the incorporation of the Bill of Rights into the Fourteenth Amendment not as the ceiling for individual rights and liberties but rather as the floor, and suggesting that state constitutions may grant liberties that extend "beyond those required by the Supreme Court's interpretation of federal law").

129. Examples of this are legion. See, e.g., Chardes Alan Wright et al., Federal. Practice AND Procedure, at Criminal 3d, $\S 52, n .46$ (West Pocket Part 2002) (listing cases from states that interpret their state version of the Fourteenth Amendment throughout constitutional criminal procedure to provide more privacy protection than the federal counterpart); Lawrence Friedman, The Constitutional Value of Dialogue and the New Judicial Federalism, 28 Hastings CONST. L.Q. 93, 97 (2000) (recommending that states continue to undertake independent analyses of their state constitutions in order to protect individual rights and liberties more extensively than the U.S. Supreme Court). 
minority ideology the opportunity to become the majority position before larger political systems terminate it, ${ }^{130}$ permitting business and individuals to vote their regulatory and lifestyle preferences with their feet, ${ }^{131}$ and preventing the strife that could lead to secession. ${ }^{132}$

The protection of independent state norms will most likely favor liberals today, so long as conservatives retain control of the federal government and liberals retain control in at least some states. Thus, today federalism may protect "liberal" causes such as the right to die, the medical use of marijuana, and same-sex marriages. ${ }^{133}$ Likewise, in the period before the Civil War, the federal government was controlled by slaveholders who enforced the Fugitive Slave Acts of 1793 and 1850 and repealed the antislavery limits in the Missouri Compromise, and it was some northern states that resisted the Fugitive Slave Law, passed Person Liberty Laws, and generally agitated to limit slavery. ${ }^{134}$ However, there is nothing inherent about the current political lineup. An outlier state on the Right, such as Florida, might choose to prohibit homosexuals from adopting children, ${ }^{135}$ and, assuming that a conservative Court finds no constitutional bar to such a law, a future liberal Congress might be later constrained by the Court and unable to legislate otherwise under either Section Five or the Commerce Clause. Whose ox federalism gores may simply depend upon who controls Congress, the Court, and each state. 1

130. Nicholas S. Zeppos, The Dynamics of Democracy: Travel, Premature Predation, and the Components of Political Identity, 50 VAND. L. Rev. 445, 447-48 (1997) (citing Romer v. Evans, 517 U.S. 620 (1996), as an cxample of the Supreme Court permitting a smaller community to live a minority lifestylc, thus permitting others in and out of the statc to vote thcir preferences with their feet, and suggesting that the decision can best be explained under a theory of democracy that prevents larger political systems from killing off a potentially competitive minority ideology).

131. See, e.g., Jennifer Gerarda Brown, Competitive Federalism and the Legislative Incentives to Recognize Same-Sex Marriage, 68 S. CAL. L. Rev. 745, 747 (1995) (suggesting that states may compete to become the first to recognize same-sex marriages, with the prize of over four billion dollars in revenue likely to flow to the first state); Richard A. Epstein, Exit Rights Under Federalism, 55 Law \& CONTEMP. Probs. 147 (1992); Jonathan R. Macey, Federal Deference to Local Regulators and the Economic Theory of Regulation: Toward a Public Choice Explanation of Federalism, 76 VA. L. REv. $265(1990)$.

132. See, e.g., Steven G. Calabresi, A Government of Limited and Enumerated Powers: In Defense of United States v. Lopez, 94 MicH. L. REv. 752, 765 (1995) (suggesting that the United States and Switzerland are federalism success stories because both have a large number of subunits which "provide plenty of opportunities for social minority groups to dominatc particular federal subentities without encouraging secession"); Michael C. Dorf \& Charles F. Sabel, A Constitution of Democratic Experimentalism, 98 Colum. L. REv. 267 (1998); Clayton P. Gillete, The Exercise of Trumps by Decentralized Governments, 83 VA. L. Rev. 1347 (1997).

133. See infra Part I11.

134. See generally Paul Finkclman, Teaching Slavery in American Constitutional Law, 34 AKRON L. REv. 261 (2001) (detailing the unsuccessful attempts by northern states to assist slaves and freed blacks in the face of congressional and Court opposition); Robert J. Kaczorowski, The Tragic Irony of American Federalism: National Sovereignty Versus State Sovereignty in Slavery and in Freedom, 45 U. KAN. L. REv. 1015 (1997) (suggesting that federalism is not one of the "first principles" of the Founders, as Congress used the fugitive Slave Acts to reduce state sovcreignty and curb state police powers).

135. Fla. Stat. $\$ 63.042(2001)$. 
cannot here resolve the debate about whether independent-norm federalism is a desirable goal. I note only that Professor Rubin is only partly correct in calling our country essentially homogeneous, and hope that any serious disagreement between the states and the federal government regarding what conduct should be made criminal will be small.

\section{B. Current Commerce Clause and Section Five Jurisprudence}

Regardless of whether Court protection of independent norms is wise, current Supreme Court federalism jurisprudence is pushing us, perhaps inadvertently, in this direction. The 1997 term marked a departure from prior precedent in congressional authority to legislate im furtherance of the substantive guarantees of the Fourteenth Amendment. Presently, if Congress wants to regulate private conduct implicating civil rights, ${ }^{136}$ it has to use the Commerce Clause or some other enumerated power, not Section Five of the Fourteenth Amendment. Legislation under Section Five must remedy a constitutional violation engaged $\mathrm{m}$ by the state, not by private actors, and the remedy must be congruent and proportional to the injury to be prevented or harm to be remedied. ${ }^{137}$ However, where the legislature does not directly enforce a provision of the Constitution or Bill of Rights, and therefore cannot use Section Five, it may nonetheless regulate pursuant to the Commerce Clause if the activity im question is clearly economic or has an economic or physical spillover effect onto another state. ${ }^{138}$ The single reason to cheer the Court's narrowing of Section Five and its shunting of those cases to Commerce Clause analysis is that such a requirement may curb federal legislation that seeks to impinge upon independent state norms which advance civil rights. For example, federal legislation criminalizing same-sex marriage cannot be upheld under Section Five, as it does not remedy a constitutional violation, and likewise, as I will demonstrate in

136. For instance, by providing a cause of action to the elderly discriminated against in employment, or by providing a cause of action for persons assaulted because of gender, see 42 U.S.C. $\S 139(2000)$.

137. Bd. of Trs. of the Univ. of Ala. v. Garrett, 531 U.S. 356, 374 (2001) (holding that Congress had no authority under the Fourteenth Amendment to apply the Americans with Disabilities Act to the states); City of Boerne v. Flores, 521 U.S. 507, 511 (1997) (holding that the Religious Freedom Restoration Act of 1993 was unconstitutional because Congress was not attempting to remedy a violation of the Fourteenth Amendment). Scholars faulting the Court's Section Five interpretation include Samuel Estreicher \& Margaret H. Lemos, The Section 5 Mystique, Morrison, and the Future of Federal Antidiscrimination Law, 2000 SuP. CT. REv. 109 (2000), and Lawrence G. Sager, A Letter to the Supreme Court Regarding the Missing Argument in Brzonkala v. Morrison, 75 N.Y.U. L. REv. 150 (2000).

138. Kimel v. Fla. Bd. of Regents, 529 U.S. 62 (2000) (holding that Congress had the authority to enact the Age Discrimination in Employment Act of 1967 under the Commerce Clause but not under Section Five of the Fourteenth Amendment because the Act imposed substantive requirements disproportionate to any unconstitutional conduct targeted by the Act); $c f$. United States v. Morrison, 529 U.S. 598, 602 (2000) (finding that Congress lacked authority under both Section Five of the Fourteenth Amendment and the Commerce Clause to enact the civil provision of the Violence Against Women Act). 
Part III, it cannot be upheld under the Commerce Clause, as it does not regulate an economic transaction.

The change in Commerce Clause analysis has been just as radical as the change in Section Five jurisprudence. From about the early 1940s, the Court has allowed Congress to regulate purely intrastate activities "affecting commerce," rather than limiting regulation to commerce involving more than one state. ${ }^{139}$ This third category of permissible Commerce Clause regulation ${ }^{140}$ permitted regulation of an entire "class of activities... without proof that the particular intrastate activity against which a sanction was laid had an effect on commerce."141 Because of the breadth of this third test, not a single federal statute was invalidated on Commerce Clause grounds post-New Deal until the federalism revolution began in 1995. The Court's new limits on federal power all concern the third test for determining whether a federal statute is validly enacted under the Commerce Clause: that it affect interstate commerce. The first limit requires the effect on commerce from the regulated behavior be substantial. ${ }^{142}$ Second, the activity regulated (probably) must be economic in nature. ${ }^{143}$ Third, the link between the regulated activity and its effect on interstate commerce cannot be attenuated. ${ }^{144}$

As with the Court's narrowing of congressional power under Section Five of the Fourteenth Amendment, these limits potentially enhance independent-norm federalism and allow states to create more (but never less) protection of individual rights than mandated by the Constitution. The cumulative effect of these new limits may be to allow a state to experiment

139. Thus, Wickard v. Filburn, 317 U.S. 111 (1942), which upheld the regulation of wheat grown on a farm solely for home consumption because, though never marketed interstate, it supplied the needs of the grower which otherwise would have been satisfied by his purchase in the open market, won out over Gibbons v. Ogden, 22 U.S. 1, 9 Wheat 1 (1824). See Justice Douglas' opinion in Perez v. United States, 402 U.S. 146, 151-55 (1971), for a nice description of the return to the substantial-effects test during the New Deal.

140. In addition to (1) the channels of interstate or foreign commerce, and (2) the instrumentalities of interstate commerce or persons or things in commerce.

141. Perez, 402 U.S. at 152.

142. United States v. Morrison, 529 U.S. 598, 610 (2000); United States v. Lopez, 514 U.S. 549, 559 (1995) (noting that "the proper test requires an analysis of whether the regulated activity 'substantially affects' interstate commerce").

143. Morrison, 529 at 613 ("While we need not adopt a categorical rule against aggregating the effects of any noneconomic activity in order to decide these cases, thus far in our Nation's history our cases have upheld Commerce Clause regulation of intrastate activity only where that activity is economic in nature."); Lopez, 514 U.S. at 561 ("Section 922(q) is a criminal statute that by its terms has nothing to do with 'commerce' or any sort of economic enterprise.").

144. Morrison, 529 U.S. at 615 ("The reasoning that petitioners advance seeks to follow the butfor causal chain from the initial occurrence of violent crime... to every attenuated effect upon interstate commerce. If accepted, petitioners' reasoning would allow Congress to regulate any crime."); Lopez, 514 U.S. at 567 (To uphold the government's "cost of crime" or "national productivity" arguments, "we would have to pile inference upon inference in a manner that be fair to convert congressional authority under the Commerce Clause to a general police power of the sort retained by the States."). 
with different noneconomic norms. This is first because the limits on the third category will force much legislation back into an analysis under the first two categories of the Commerce Clause, regulating the chaunels of interstate commerce and protecting the instrumentalities of interstate commerce. Those nonsubjective categories require either physical trespass onto a neighboring state or interference with transportation routes. Second, to be upheld, the few cases remaining in the third category must at the very least produce economic externalities on neighboring states. Limiting Congress to the regulation of commercial activity, and perhaps to noncommercial activity that has a direct and substantial economic effect in a neighboring state, will allow states to protect minority noneconomic norms so long as there are few economic or physical externalities beyond their borders. ${ }^{145}$

If one is going to impose a federalism doctrine policed by the judiciary, the Court's current test, at least as I interpret it, is an improvement over prior formulations. Though the question of whether or not an effect is "substantial" leaves a lot of wiggle room, it also clearly raises the bar to finding Commerce Clause authorization. Moreover, it seeins no more subjective than the attempt to differentiate between a "legitimate" state purpose and an "important" one. ${ }^{146}$ The requirement that the activity be "commercial" in nature is arguably inore legitimate and sensible than distinctions made prior to the New Deal. It is legitimate because it is grounded in the text of the Constitution-after all, we are construing the Commerce Clause. The old distinctions between manufacturing, ${ }^{147} \mathrm{~min}$ ing, ${ }^{148}$ and union activities, ${ }^{149}$ which were not commerce, and distribution, which was commerce, had no grounding in the text of the Constitution, no relation to regulating a national economy, and in fact severely limited the ability of Congress to regulate the national economy. ${ }^{150}$

On the other hand, the new limit requiring a commercial transaction is very broad, and would plainly allow all New Deal legislation to stand. It is also somewhat less subjective: people either make, keep, lose, or barter money, services, or property, or they do not. In the criminal-law area, prohibiting Congress from regulating noncommercial activity is more likely to

145. This presumes that the test for the third category is sufficiently objective, and that the Court must apply it to protect disfavored as well as favored state norms. See infra Part III.

146. Craig v. Boren, 429 U.S. 190, 197 (1976) (requiring that laws classifying on the basis of gender "must serve important governmental objectives" rather than simply legitimate ones).

147. United States v. E.C. Knight Co., 156 U.S. 1, 12-16 (1895) (distinguishing "commerce" from "manufacture").

148. Oliver Iron Mining Co. v. Lord, 262 U.S. 172, 178 (1923) ("Mining is not interstate commerce, but, like manufacturing, is a local business.").

149. NLRB v. Jones \& Laughlin Steel Corp., 301 U.S. 1 (1937); Carter v. Carter Coal Co., 298 U.S. 238, 303 (1936) (holding that regulation of unfair labor practices in mining regulated "production" not "commerce").

150. See, e.g., Lopez, 514 U.S. at 577 (noting that Congress may "regulate in the commercial sphere on the assumption that we have single market and unified purpose to build a stable national economy"). 
protect private behavior when the impetus for the prohibition is morality rather than economic regulation. Thus federal statutes prohibiting crimes involving money such as extortion under the Extortionate Credit Act, ${ }^{151}$ robbery under the Hobbs Act, ${ }^{152}$ racketeering under RICO, ${ }^{153}$ and a host of others, ${ }^{154}$ will continue to be upheld using the substantial-effects test even when purely intrastate, whereas those prohibiting purely intrastate crimes of passion, such as murder, rape, assault, or throwing a Molotov cocktail into the home of your cousin, ${ }^{155}$ and crimes against public morals, such as sodomy and incest laws, would most likely not be. Finally, the attenuation limit is subject to the charge of a return to the failed direct-versus-indirect test of the New Deal Supreme Court. ${ }^{156}$ While this charge of subjectivity has merit, the attenuation test is no more subjective than the proximatecause analysis courts and juries apply daily in civil and criminal cases. ${ }^{157}$

151. Perez v. United States, 402 U.S. 146 (1971). The Extortionate Extension of Credit Act is codified at 18 U.S.C. $\$ 893(2000)$.

152. United States v. Culbert, 435 U.S. 371, 372 (1978); United States v. Green, 350 U.S. 415, 420-21 (1956) (upholding Congress's power to enact the Hobbs Act, which prohibits extortion and robbery that "in any way or degree... affects commerce"). The Hobbs Act is codified at 18 U.S.C. $\S 1951(2000)$.

153. Criminal RICO, codified at 18 U.S.C. $§ 1962$ (a) (2000), like the Hobbs Act, has two potential jurisdictional hooks. The enterprise must either affect commerce or be cngaged in commerce. The latter hook was blessed by the Supreme Court in United States v. Robertson, 514 U.S. 669, 670-71 (1995) (per curium) (upholding a criminal RICO prosecution against a Commerce Clause challenge because the mining business itself was engaged in interstate commerce and used the channels of interstate commerce by, for example, bringing in workers from out of state and investing money in one state for equipment transported to another state).

154. See, e.g., 7 U.S.C. $\$ 2024$ (2000) (prohibiting food-stamp fraud); 18 U.S.C. $\$ 248$ (2000) (prohibiting blockading a healthcare business); 18 U.S.C. $\$ 1033$ (2000) (prohibiting crimes by or affecting persons engaged in the business of insurance); 18 U.S.C. $\$ \S 1956,1957$ (2000) (prohibiting the laundering of money derived from unlawful activity); 18 U.S.C. $\S 2113(2000)$ (prohibiting larceny and robbery of federally insured banks); 21 U.S.C. $\$ 841$ (2000) (prohibiting the distribution of controlled substanccs); 21 U.S.C. $\S 848$ (2000) (prohibiting a continuing criminal enterprise that derives substantial income from drug sales).

155. Jones v. United States, 529 U.S. 848 (2000); United States v. Morrison, 529 U.S. 598, 615 (2000) (noting that "if Congress may regulate gender-motivated violence, it would be able to regulate murder...").

156. A.L.A. Schechter Poultry Corp. v. United States, 295 U.S. 496 (1935), overruled by N.L.R.B v. Jones \& Laughlin Steel, 301 U.S. 1 (1937).

157. See, e.g., Holmes v. Sec. Investor Prot. Corp., 503 U.S. 258, 267-68 (1992) (importing proximate-cause analysis into civil RICO claim); MODEL PENAL CODE, $\$ 2.03$ (1985) (requiring causal relationship between conduct and result); Deborah Jones Merritt, Commerce!, 94 MiCH. L. REv. 674, 679 (1995). Professor Merritt wrote:

[T] he majority's use of "substantial effect" is more akin to the notion of proximate cause in tort law. The Lopez majority meant that the relationship between the regulated activity and interstate commerce must be strong enough or close enough to justify federal intervention, just as the concept of proximate cause means that a defendant's negligence must be closely enough related to the plaintiff's injury to justify forcing the defendant to bear the costs of the injury.

Id. Although Professor Merritt ascribes the proximate-cause analysis to the addition of the word "substantial" rather than to the addition of the requirement that there be a direct effect, 1 think we ultimately arrive at the same destination. 
Most of the scholarly criticism of the Court's new limits on the third category of cases concern the commercial-noncommercial distinction. For example, Professor Regan chides the Court for providing "no justification for distinguishing between commercial behavior that affects interstate commerce and noncommercial behavior that does the same." $158 \mathrm{He}$ then gives us examples under

which Congress's power to regulate noncommercial local behavior under the Commerce Clause should be obvious. Surely Congress can regulate private sport-hunting of migratory birds or drunk driving on interstate highways or backyard incinerators if they are found to emit some airborne toxic chemical that is deposited hundreds of miles from the site of incineration. ${ }^{159}$

While the drunk driving example can easily be regulated under the channels or instrumentalities tests, ${ }^{160}$ the other examples give us pause.

One solution for the remaining two examples is to say that national consumer safety and environmental regulation are regulations of commerce, and including purely intrastate activity is an essential part of the larger regulatory scheme. ${ }^{161}$ One could also try to fit these examples into one of the other two categories of Commerce Clause analysis by noting that birds and pollution physically cross state lines. The Court should be unwilling to allow one state to economically injure another state, negatively affecting the national economy. Thus, when there is economic spillover from one state to another, even when the activity causing the spillover is not commercial, regulation under the affecting-commerce test is appropriate. ${ }^{162}$ The citizens of Georgia should not have to pay to clean up pollution created by the citizens of Florida, and Colorado should not lose the natural treasure of its parks (not to mention the admission fees) because the citizens of Georgia killed their wildlife. Such an economic-spillover test would certainly solve the migratory-bird problem. 1 believe this is where the Court is heading, despite the five-four decision in Solid Waste Agency of Northern Cook County v. United States Army Corps of Engineers, which held that, as a matter of statutory construction, the Clean

158. Donald H. Regan, How to Think About the Federal Commerce Power and Incidentally Rewrite United States v. Lopez, 94 Mich. L. Rev. 554, 566 (1995).

159. Id. at 564 .

160. In this Section, I discuss only the affecting-commerce test. In notes 171-74 and accompanying text, infra, I will discuss the other two justifications: regulation of the instrumentalities of commerce and regulation of the channels of commerce. Interstate highways are part of the national infrastructure of interstate travel, and drunk drivers also threaten other goods and persons traveling in interstate commerce.

161. See infra note 231 .

162. Perhaps this is why Justice Rehnquist refused to "adopt a categorical rule against aggregating the effects of any noneconomic activity." United States v. Morrison, 529 U.S. 598, 613 (2000). 
Water Act did not permit the rcgulation of intrastate waters used by migratory birds. ${ }^{163}$

Professor Lessig criticizes a different aspect of the commercialnoncommercial distinction. He argues, first, that the rule is indeterminate because the same activity can be defined narrowly as noncommercial or broadly as commercial. ${ }^{164}$ For example, the Civil Rights Act of 1964 is illegitimate if the activity is defined as "discriminating" rather than as preventing the use of hotels and restaurants during travel, and the federal arson statute is illegitimate if the arson is committed for vengeance rather than for insurance fraud. ${ }^{165} \mathrm{He}$ also claims that even if we could define the activity being regulated, there is no objective method for determining whether the particular activity is commercial or not; this "is simply the old line drawn and undermined in National League of Cities, namely, the line focusing on objects of traditional state concern."166

These criticisms are valid but overstated. We have a general sense that, in addition to the transportation routes themselves, "commerce" concerns an economic transaction, a sense shared by the Court. ${ }^{167}$ The activity defined in the Civil Rights Act is not simply discriminating, as all forms of

163. 531 U.S. 159,162 (2001). The majority found that there was no congressional acquiescence in this administrative interpretation of the statute, and that the argument that intrastate water not adjacent to open waters is covered by the act raised "significant constitutional questions." Id. at 174 . The constitutional questions concerned (1) whether the activity regulatcd, which in the aggregate must substantially affect interstate commerce, involved water areas used by migratory birds or commercial landfills, and (2) whether such regulation would 'result in a siguificant impingement on the States' traditional and primary power over land and water use." Id. Were Congress to amend the statute to comport with the agency interpretation, then the dissenters' argument that the activity regulates commerce under the Court's present test is quite strong. The purpose of the Clean Water Act is not land-use regulation to protect the navigability of water, but environmental regulation to protect our natural resources, an acceptable exercise of federal power. Id. at 191 (Stevens, J., dissenting) (citing Hodel v. Virginia Surface Mining \& Reclamation Ass'n, 452 U.S. 264 (1981)). The requirement that the activity regulated be a commercial one is met since the discharge of the fill material is undertaken for economic reasons, and the class of activity affects commerce by hurting migratory birds, which, in addition to their intrinsic value, generate millions or perhaps billions of dollars in commercial activities such as bird-watching and hunting. Id. at 195 . This is a paradigmatic economic-spillover problem; the landfill benefits the state doing the filling, but imposes much of its external costs on surrounding states. See Richard L. Revesz, Federalism and Interstate Environmental Externalities, 144 U. PA. L. REv. 2341,2343 (1996). Moreover, the fact that the birds themselves cross state lines provides a sufficient jurisdictional nexus for federal regulation. However, if I am wrong, and the application of the Clean Water Act to purely intrastate bodies of water is prohibited under the Commerce Clause, then surely all three of the state norms I discuss in Part III of this Essay are also off-limits for federal regulation; otherwise, the Court is engaging in expressly political decisions which cannot stand the test of time.

164. Lawrence Lessig, Translating Federalism: United States v. Lopez, 1995 Sup. CT. REv. 125 (1995). Likewise, Professor Moulton argues that "gun possession ought reasonably to be understood as commercial activity" because guns are both articles of commerce and instruments used to further or impede commercial aims. Moulton, supra note 26, at 888 . His mistake is that neither of these nexuses to commerce (travel in commerce or use of the gun in commerce) were part of the criminal offense.

165. Lessig, supra note 164, at 204.

166. Id. at 205-06.

I67. Nat'l Org. for Women, lnc. v. Scheidler, 510 U.S. 249, 252 (1994) (holding that a RICO enterprise need not have an underlying economic motive, defined as a desire to make money). 
discrimination are not prohibited. Rather, it is discriminating in the use of those commercial businesses, such as hotels and restaurants, that are necessary for interstate travel. Likewise, the arson statute interpreted narrowly in Jones criminalizes the activity of burning a structure; the motive for such burning is irrelevant to the crime. ${ }^{168}$ Finally, though Professor Lessig is correct that the Court states that "depending on the level of generality, any activity can be looked upon as commercial,"169 he neglects to mention that the majority here is criticizing Justice Breyer's dissenting definition of "commercial." While it is true that what is not commercial will generally fall into categories of traditional state concern, ${ }^{170}$ such as family law and education, the breakdown will not be precise: defining marriage might be reserved for the state, but selling one's child or pimping one's husband could be prohibited federally.

While the scholarship and recent Supreme Court Cominerce Clause cases primarily focus on the third test, regulating intrastate activities which affect commerce, the Court's clear affirmation of the other two categories of Cominerce Clause authority is of at least equal significance. These two categories are (1) regulating the use of channels of interstate or foreign commerce where Congress finds they are being misused, and (2) protecting the instrumentalities of interstate commerce, or persons or things in commerce, from intrastate threats. ${ }^{171}$ By refusing to extend any of the limits placed on the third category to the first two, the Court can stay out of decentralization federalism and protect independent-norm federalism through a relatively nonsubjective physical and economic-spillover test. The majority of federal criminal statutes mvolves the transportation of persons or things in interstate commerce, and thus fits neatly under one of these two categories. ${ }^{172}$

168. In Jones, the Court limited the statute to the burning of a business rather than a private residence. Jones v. United States, 529 U.S. 848,848 (2000). The mens rea element for the federal arson statute is simply the intent to burn. One could make a plausible argument for the constitutionality of a statute criminalizing the arson of a private residence for the purpose of collecting insurance proceeds, provided one could show either that the insurance company was headquartered in a different state, or that the cumulative effect of such fraud on the insurance industry was substantial.

169. Lessig, supra note 164, at 205 (quoting United States v. Lopez, 514 U.S. 549, 565 (1995)).

170. Lopez, 514 U.S. at 568-69 (Kennedy, J., concurring).

171. United States v. Morrison, 529 U.S. 598, 612 (2000) (opining favorably on the criminal provision of the VAWA, which requires that the crime against the intimate partner be committed during interstate travel or by spouses who cross state lines to continue the abuse); Lopez, 514 U.S. at 558 (noting the authority of Congress to "'keep the channels of interstate commerce free from immoral and injurious uses" and Congress's authority "to regulate and protect the instrumentalities of interstate commerce, or persons or things in interstate commerce, even though the threat may come only from intrastate activities").

172. Examples imclude transporting lottery tickets and obscene literature from one state to another, 18 U.S.C. $\$ 1302(2000)$; transporting a female across state lines for the purpose of prostitution or other immoral purpose, 18 U.S.C. $\$ 2421$ (2000); transporting stolen motor vehicles, 18 USC $\$ \S 2311-2313$ (2002); transporting a kidnapped person, 18 U.S.C. $\$ \S 1201-1202$ (2000); stealing shipments from interstate or foreign carrier, 18 U.S.C. $\$ 659$ (2000); interstate communications of extortions or threats, 
Though commentators and jurists alike poke fun at the requirement of movement across state lines as the dividing line between what is truly national and what is truly local, ${ }^{173}$ it serves two very useful purposes. First, it allows the federal government to regulate whenever the conduct at issue directly and physically impinges upon a neighboring state. It is one thing to allow a minority norm to exist confined to the single locality that desires it; it is another thing to say the national polity has no authority to prevent the unwanted norm from spreading into states opposed to it. Second, this test is grounded in the text of the Constitution, which permits regulation of commerce "among the several States." 174 Finally, the test is an objective one. The behavior, person, or item either moves from one state to another or it does not. A conservative and liberal jurist cannot disagree.

Thus, purely intrastate federal crimes of a commercial nature ${ }^{175}$ should be valid under the substantial-effects test. Any federal crimes involving movement across state lines, whether commercial or not, will also be valid under one of the first two Commerce Clause tests. This potentially leaves a

18 U.S.C. $\$ 875$ (2000); traveling in interstate commerce with the intent to commit extortion, bribery, or arson under state law, 18 U.S.C. $\$ 1952$ (2000); possession by a felon of a firearm that has been transported in interstate commerce, 18 U.S.C. $\S 922(\mathrm{~h})(2000)$; alien smuggling, 18 U.S.C. $\S 1324$ (2000); interstate stalking and domestic violence, 18 U.S.C. $\S \S 2261-62$ (2000); acts of terrorism transcending national boundaries, 18 U.S.C. $\S 2332(2000)$; transporting stolen goods, securities or money, 18 U.S.C. $\$ \S 2314-15$ (2000); fraud executed though interstate wire transmissions, 18 U.S.C. $\S 1342$ (2000); importing controlled substances, 18 U.S.C. $\S 952$ (2000); use of interstate commerce facilities in the commission of murder-for-hire, 18 U.S.C. $\$ 1958$ (2000); shipping diseased livestock, 18 U.S.C. $\S 42$ (2000); crossing a state line to avoid prosecution, 18 U.S.C. $\$ 1073(2000)$; and so on. Forty percent of federal criminal convictions are brought pursuant to controlled substance statutes, which are justified under the class-of-activities-affecting-commerce rationale. It would be difficult to argue in unost instances that drug distribution is anything but a commercial transaction involving a national market. But see infra Part III.A, notes 238-41 (suggesting a different result for drug possession, where state regulation prevents the interstate distribution of the drug).

173. As Judge Henry Friendly put it, "Why should the federal government care if a Manhattan businessman takes his mistress to sleep with him in Greenwich, Connecticut, although it would not if the love nest were in Port Chester, N.Y.?" HENRY J. Friendly, Federal JuRisdiction: A General VIEw 58 (1973). See also Kathleen F. Brickey, Crime Control and the Commerce Clause: Life After Lopez, 46 CASE W. RES. L. REv. 801, 814-15 (1995) (suggesting that if Congress were to correct the jurisdictional flaw in the Gun-Free School Zone Act by requiring that the guns have "been transported, shipped or received in interstate commerce ... the underlying social concern would be precisely the same as before-the adverse impact of violent crime on the educational process"); Grant S. Nelson \& Robert J. Pushaw, Jr., Rethinking the Commerce Clause: Applying First Principles to Uphold Federal Commercial Regulations But Preserve State Control over Social Issues, 85 Iowa L. REv. 1, 10-11 (1999) (suggesting that the limits in Lopez should be applied to the first two categories of cases as well, and that physically crossing a state boundary is inadequate justification for federal regulation).

174. U.S. ConST. art. $1, \S 8$, cl. 5 .

175. See supra notes 151-54. But see United States v. Hickman, 179 F.3d 230, 231 (5th Cir. 1999) (upholding a Hobbs Act conviction by an equally divided en banc court). Dissenters argued that the robbery of a local sandwich shop cannot be prosecuted under the Hobbs Act after Lopez, first, because robbery is not an economic activity, and second, because the effects on commerce of individual acts of robbery are causally independent and therefore cannot be aggregated to produce a substantial effect. Id. It seems to me that the claim that a monetary transaction is not economic because it is involuntary is quite a stretch, and the requirement of causal dependency is made up of whole cloth. 
very narrow opportunity for states to protect noneconomic minority norms from federal encroachment.

One potential wrinkle in my claim that modern Commerce Clause jurisprudence requires a physical entry or economic-spillover effect into another state is the Court's lamentation in Lopez and Morrison over the lack of an express jurisdictional element requiring that the particular conduct criminalized affect interstate commerce. ${ }^{176}$ One might argue that all Congress need do to circumvent the Court's new limits on the effects test is to add as an element of the criminal offense that it affects commerce. ${ }^{177}$

This wrinkle is presently being ironed out by lower courts interpreting the Hobbs Act, which require that the robbery or extortion "affect cominerce." 178 Some lower courts, for example, are holding that a 1960 Supreme Court case requiring only a de mimimis effect on commerce ${ }^{179}$ survives Lopez, and they are upholding all Hobbs Act convictions regardless whether the behavior regulated is commercial or whether the classwide effect of the behavior on commerce is substantial. ${ }^{180}$ Other courts are requiring that the individual robbery before them have a substantial effect on commerce. ${ }^{181}$ The third and, in my opinion, correct approach requires that the class of activity in the aggregate directly and substantially effect commerce, but that the individual case need only have a de minimis effect. $^{182}$

Clearly the Court intended, by placing such stringent requirements on the effects test in Lopez and Morrison, to police the limits of Congress's Commerce Clause authority, regardless of whether Congress itself finds that the activity affects commerce ${ }^{183}$ or places the "affecting commerce" language in a statute and leaves that finding to a jury. Thus, for the Hobbs

176. See Morrison, 529 U.S. at 613 ("Section 13981 contains no jurisdictional element establishing that the federal cause of action is in pursuance of Congress' power to regulate interstate commerce ... Lopez makes clear that such a jurisdictional element would lend support to the argument that section 13981 is sufficiently tied to interstate commerce...."); Lopez, 514 U.S. at 561 ("[S]ection 922(q) contains no jurisdictional element which would ensure, through case-by-case inquiry, that the firearm possession in question affects interstate commerce.").

177. This is suggested in George D. Brown, Constitutionalizing the Federal Criminal Law Debate: Morrison, Jones and the $A B A, 2001$ U. ILL. L. Rev. 983, 985 (2001).

178. 18 U.S.C. $\$ 1951$ (a) (1994). One can also violate the statute by obstructing or delaying commerce, but the constitutional authority to prevent that is clear.

179. Stirone v. United States, 361 U.S. 212, 215 (1960) (affecting commerce "'in any way or degree"" sufficient for Hobbs Act violation).

180. See, e.g., United States v. Kaplan, 171 F.3d 1351, 1355 (11 th Cir. 1999); United States v. Stillo, 57 F.3d 553, 558 (7th Cir. 1995), cert. denied, 516 U.S. 945 (1995).

181. United States v. Harrington, 108 F.3d 1460, 1467 (D.C. Cir. 1997) (requiring that the effect on commerce of the particular robbery be "concrete").

182. See, e.g., United States v. Jones, 178 F.3d 479, 481 (7th Cir. 1999) (upholding arson conviction against Commerce Clause challenge by considering the "collective effect, plus proof of a slight connection between the particular [crime] and interstate commerce"); rev'd, 529 U.S. 848, 85051 (2000) (finding that Congress did not intend for arson statute to cover private residence).

183. Morrison, 529 U.S. at 615 (discounting Congressional findings). 
Act to survive, the Court must first determine that the class of intrastate activity regulated, here, robbery, substantially affects commerce, that the effect of robbery on the economy is not too attenuated, and that the activity regulated is a commercial one. In addition, due to the existence of the jurisdictional hook, in each particular case the jury also has to find that the particular robbery charged has a de minimis effect on commerce. Therefore, even though the national class of all robberies substantially affects interstate commerce, in a particular criminal prosecution, an individual may be acquitted because he robbed a homeowner, and his robbery did not affect interstate commerce. ${ }^{184}$ Surely the Court could not have intended to say in Morrison that Congress has no authority to regulate an intrastate activity unless the Court concurs that the activity is a commercial one that, as a class, directly and substantially affects interstate commerce, yet Congress can regulate an essentially intrastate noncommercial activity that does not substantially affect commerce where the jury finds a de minimis impact in an individual case. ${ }^{185}$

Instead, what the Lopez Court intended when it suggested a jurisdictional element was a requirement that the gun itself have been transported in interstate commerce, thus moving the case to the channel-of-commerce category. ${ }^{186}$ Alternatively, the Court might have intended a jurisdictional requirement limiting convictions to the possession of guns intended to be used in the drug trade, a type of activity that as a class would substantially affect commerce. ${ }^{187}$ If the jurisdictional hook is to supplant a finding of a cumulative substantial effect by Congress and the Court, it cannot be sufficient for every individual case to have a de minimis impact that does not add up in the aggregate to a direct and substantial effect. When the Morrison Court mentioned the lack of a jurisdictional element supporting the civil cause of action under the VAWA, it cited to the criminal cause of action under that statute, requiring that a partner cross state lines to commit or facilitate the abuse. This again shifts the analysis to the

184. See, e.g., United States v. Collins, 40 F.3d 95, 99-100 (5th Cir. 1994), cert. denied, 514 U.S. 1121 (1995) (relying on Lopez, rejecting application of the Hobbs Act to robbery of a homeowner's cash, jewelry, clothes, and car). This is in contrast to courts upholding Hobbs Act prosecutions where the defendant extorted or robbed a business that made purchases or sales across state lines. See, e.g., Stirone, 261 U.S. at 212; United States v. Davis, 30 F.3d 613, 614 (5th Cir. 1994).

185. See, e.g., United States v. Hickman, 179 F.3d 230, $240-41$ (1999) (Higginbotham, J., dissenting) ("A jurisdictional element by itself cannot save a statute that exceeds congressional authority. The jurisdictional element must in some way be meaningful, and the Supreme Court has specified a condition for meaningfulness in its substantial effects test.").

186. This explains the Court's citation to a number of cases and statutes imposing such an interstate transportation requirement. Lopez, 514 U.S. at 561-62 (1995) (citing United States v. Bass, 404 U.S. 336 (1971); United States v. Five Gambling Devices, 346 U.S. 441 (1953)).

187. United States v. Kirk, 104 F.3d 997 (6th Cir. 1997) (affirming conviction under 18 USC $\S 22(0)$, prohibiting possession of a machine gun acquired after 1986 , by an equally divided en banc court as machine guns have a substantial effect on interstate commerce by facilitating trade in illegal drugs). 
channels-of-commerce test. If, in the aggregate, instances of violence against women do not sufficiently and directly affect commerce enough to allow such regulation under the Commerce Clause, it is difficult to argue that particular acts of violence, where there is no crossing of state lines and a mere de minimis effect on commerce, are validly regulated under the Commerce Clause.

\section{A Better Test?}

My interpretation of the Court's present test is that it permits federal regulation under the Commerce Clause whenever there is an economic spillover from the regulated behavior on another state (the substantialeffects test) and whenever the state fails to physically contain the activity within its own borders (the channels-and-instrumentalities test). It is irrelevant whether the purpose of the regulation is to beneficially enhance commerce and to protect transportation routes or whether the purpose is strictly to prohibit immoral behavior. However, the latter purpose, when decoupled from interstate movement or direct economic-spillover effects, will be insufficient to override contrary state views of moral behavior. I am not going so far as to claim that my restatement of the current Commerce Clause test is the law; rather, I am claiming that ny view is consistent with what the Court has said and is a sensible elaboration of where the Court seems to be headed. Moreover, despite the inconsistencies and nuances yet to be resolved, I believe that this test, at least as I interpret it, may be the best the Court can do, if we define "best" as a relatively stable test that permits decentralization, protects minority norms, and is less subjective than plausible alternatives. I support this conclusion by examining other proposals.

One such proposal, hinted at by the Court in Lopez and Morrison, would develop categories of national versus local activities. ${ }^{188} \mathrm{I}$ believe that a move to delineate specific categories would be a mistake. The Court would put not only family law and education but also criminal law on the nonfederal side of the line. This would be unfortunate, as much crime cannot be controlled by states. ${ }^{189}$ On the other hand, under the substantialeffects test, family law and education will stay, for the most part, off-limits

188. Morrison, 529 U.S. at 608,618 (warning that the Commerce Clause test inust not be allowed to "obliterate the distinction what is national and what is local" and stating that the test suggested by the government would allow Congress to regulate any type of violent crime as well as family law as "[the Court could] think of no better example of the police power, which the Founders denied the National Government and reposed in the States, than the suppression of violent crime and vindication of its victims"); Lopez, 514 U.S. at 564 (criticizing the government's national productivity theory as it would allow regulation of family law, criminal-law enforcement, and education where "[s]tates historically have been sovereigu").

189. For example, there is almost universal agreement that certain misconduct, such as crimes committed by transnational and national organizations and crimes that interfere with the core functions of the federal government, should be the subject of federal criminal law. See, e.g., James A. Strazzella, The Federalization of Criminal Law, 1998 A.B.A. SEC. CRIM. JUST. L. REP. 56. 
to the federal government, while crimes involving money and property will be fair game. Moreover, under the present channels-and-instrumentalities test, family law, criminal law, and other local concerns remain off-limits unless they involve movernent across state lines.

This alternative also assumes that such categorization is even possible. As Justice Souter reminded us in his dissent in Morrison, the "effort to carve out inviolable state spheres" has already been tried and rejected as incoherent. ${ }^{190}$ Professor Resnik suggested that an attempt to identify the "truly national" from the "truly local" by reference to the Founding is doomed, for the federal had not yet been made at the time of the Founding. ${ }^{191}$ Such categories are politically based judgments about which government should regulate such activities rather than an interpretation of whether the particular federal statute regulates commerce. Though some scholars argue otherwise, ${ }^{192}$ I believe the Court has learned its lesson and will not attempt to revive "dual federalism."193

190. Morrison, 529 U.S. at 646 (Souter, J., dissenting). The Court made this attempt in National League of Cities v. Usery, 426 U.S. 833 (1976) (striking down part of 1974 Fair Labor Standards Act as an unconstitutional intrusion into the statcs' ability to regulate internal governmental functions), but overruled it nine years later in Garcia v. San Antonio Metropolitan Transit Authority, 469 U.S. 529 (1985) (overruling Usery and upholding the application of minimum-wage provision of the Fair Labor Standards Act to the San Antonio Transit Authority).

Justice Souter levelcd the same criticism in discussing the Court's distinction between commercial and noncommercial activities. It seems to me that the commercial-noncommercial distinction is not analogous to the failed pre-New Deal distinctions between mining, production, manufaeturing, union membership, and commerce. Those distinctions, having no basis in the text of the Constitution or in logic, were, as Justice Souter rightly pointed out, no more than the Court's attempt to enshrine laissezfaire economics as constitutional doctrine. The commercial-noncommercial distinction, on the other hand, flows directly from the constitutional text (to regulate "commerce"), is exceedingly broad, and is designed to police the outer limits of the Commerce Clause powers with some judicial review.

191. Judith Resnik, Categorical Federalism: Jurisdiction, Gender, and the Globe, 111 YALE LJ. 619,620 (2001) (criticizing eategorical federalism as a political claim and an unworkable principle). Professor Resnik also notes that, as a descriptive matter, categorical federalism is incorrect, since family life and criminal law have long been subject to federal statutory and constitutional lawmaking. Id. at 644-53. See also Lessig, supra note 164, at 206. Professor Lessig noted:

There is no such thing out there called "tradition" that lower courts can look to to sort out just what objects of regulation should be federal and which local. And because there is nothing out there to guide the courts, courts will be guided to different conclusions. As these differenees percolate, and thrust themselves on the Court to resolve, the results cannot but help but seem, as they were before Garcia, inconsistent. Id.

192. See, e.g., Vicki C. Jackson, Federalism and the Uses and Limits of Law: Printz and Principle?, 111 HARv. L. REV. 2180, 2183 (1998) (suggesting that Lopez assumed "that the Constitution must be read to reserve areas for only the states to regnlate"); Moulton, supra note 26, at 865 (suggesting that in the commandeering cases the Court retumed to dual federalism); Peter M. Shane, Federalism's "Old Deal": What's Right and Wrong with Conservative Judicial Activism, 45 VILL. L. Rev. 201, 215 (2000) (suggesting that Lopez embraced dual federalism).

193. See, e.g., Edward S. Corwin, The Passing of Dual Federalism, 36 VA. L. Rev. 1, 17 (1950) (detailing the death of dual federalism in 1937); Emest A. Young, Dual Federalism, Concurrent Jurisdiction, and the Foreign Affairs Exception, 69 GEo. WASH. L. Rev. 139, 156-63, 177-85 (2001) (arguing that the federalist revival has not revived dual federalism, though the Court has yet to learn the same lesson in foreign affairs). 
This criticism of categories or dual federalism as overly subjective also applies to many of the alternative tests recently offered by scholars championing judicially enforced federalism. For example, Professor Chemerinsky has suggested a functional analysis of federalism that pragmatically assigns responsibility to state and federal governments. ${ }^{194}$ Professor Merritt has alternatively argued for protecting state autonomy through the use of the Guarantee Clause, ${ }^{195}$ and for protecting federalism through a Court-imposed "fuzzy" multifactor test, with the full array of factors yet to surface. ${ }^{196}$ Finally, Professor Regan suggests that the Court consider whether there is a special justification for federal power, such as whether there is a "general interest of the union" or whether "states are separately incompetent" to regulate the activity. ${ }^{197}$

While these functional tests are just the opposite of the sort of formalism represented by dual federalisin, the subjectivity and indeternninacy of such proposals are clear. ${ }^{198}$ For example, under Professor Merritt's first proposal, how is a court to determine which and how many limitations on state autonomy are sufficient to constitute a denial of republican government? Which particular combination of factors recognized by Professor Merritt in her second proposal, or of factors yet to be "discovered" by the Justices, will be sufficient to strike any particular piece of legislation? Likervise, Professor Regan's "general interest of the union" justification for federal regulation pursuant to the Commerce Clause is devoid of any objective descriptions. ${ }^{199}$ More important than the fact that such subjective,

194. Erwin Chemerinsky, The Values of Federalism, 47 FLA. L. REv. 499, 533-40 (1995).

195. Deborah Jones Merritt, Three Faces of Federalism: Finding a Formula for the Future, 47 VAND. L. REv. 1563, 1583-84 (1994); Deborah Jones Merritt, The Guarantee Clause and State Autonomy: Federalism for a Third Century, 88 CoLum. L. Rev. 1, 29-36 (1988).

196. Deborah Jones Merritt, supra note 157, at 693-712, 742-50 (analogizing the Commerce Clause Test to fuzzy logic, and suggesting that the Court look to factors such as whether the activity is commercial, whether there is a jurisdictional element, whether there are explicit congressional findings, whether the activity is in an area traditionally regulated by the states, whether the activity is linked to private property, whether the activity is one over which national regulation is necessary, whether the activity is a crime, and whether the activity is linked to the workplace, among others).

197. Donald H. Regan, supra note 158, at 555. Professor Althouse made a similar proposal, suggesting that the Court focus on whether federal legislation enacted pursuant to the Commerce Clause addressed a "market or other system or organization that causes harm at a national level." Ann Althouse, Enforcing Federalism After United States v. Lopez, 38 ARIz. L. REv. 793, 817 (1996).

198. Lynn Baker and Emie Young have argued that these federalism tests are no more subjective than those in individual-rights cases, yet the Court imposes strict judicial review there. Baker \& Young, supra note 9 . They point to the indeterminacy of due process, citing extensively and surprisingly to a concurring opinion in Glucksberg, where the Court rejected a substantive due process "right to die." Id. at 85-106 (citing Washington v. Glucksberg, 521 U.S. 702 (1997)). However, they fail to note that for this very reason the Court has all but abandoned free-floating due process and severely constrained substantive due process in the criminal procedure area in favor of protecting those guarantees through the more objective tests gleaned from the specific provisions of the Bill of Rights. See Susan R. Klein, Miranda's Exceptions in a Post-Dickerson World, 92 J. CRm. LAW \& CRminology 567, 574-88 (2001).

199. As Professor Moulton so aptly criticizes, its 
and therefore indeterminate, tests fail to provide guidance to the lower courts, they impermissibly allow the Justices to "deploy their discretion in pursuit of personal ideological objectives rather than abstract ideals of federalism." ${ }^{200}$ The danger of adopting a subjective rule was well stated by Professor Lessig. Where the rule is perceived as political, "the Court could not credibly constrain Congress without undermining its own institutional authority."201

There are two final proposals I would like to mention and reject. The first, mentioned by Justice Kennedy in his concurrence in Lopez, would ask whether, in enacting the federal legislation, Congress had a commercial purpose. ${ }^{202}$ As Justice Souter noted in his dissent in Morrison, this is a close cousin to the intent-based analysis rejected in Heart of Atlanta, which asked whether the intent of Congress was to regulate commerce or to regulate morals. ${ }^{203}$ Such an inquiry fails for two reasons. First, nothing about the text of the Constitution permitting the regulation of interstate commerce suggests that the regulation must be for the purpose of increasing the flow of commerce, enhancing efficiency, or maximizing money, rather than protecting interstate commerce from immoral uses. All laws are passed at least in part to further a particular moral stance, ${ }^{204}$ and criminal laws are passed in whole to condemn and deter immoral behavior. ${ }^{205}$ In

approach recognizes that federalism's central question is one of institutional choice, of deciding which level of government is best suited to solve particular problems (or to decide whether something is a problem at all).... The difficulty with searching judicial review of legislative decisions allocating government responsibility is that such decisions are often enormously complex and quite contestable, at both the empirical and the normative levels.

Moulton, supra note 26, at 915 .

200. Cross, supra note 25 , at 1329 . (suggesting that conservative Justices invoke federalism to turn down habeas petitions but ignore it when striking down state-redistricting or affirmative-action plans); Cross \& Tiller, supra note 16, at 757-62 (examining every Supreme Court decision between 1985 and 1997 and finding that conservative outcomes were favored over liberal outcomes when federalism doctrines were applied); Sue Davis, Rehnquist and State Courts: Federalism Revisited, 45 W. Pol. Q. 773, 777-81 (1992) (analyzing every nonunanimous civil-liberties decision and finding Justices influenced most by the ideological posture of the case); William N. Eskridge, Jr. \& John Ferejohn, The Elastic Commerce Clause: A Political Theory of American Federalism, 47 VAND. L. Rev. 1355, 1396 (1994) (reviewing twenty-eight major federalism cases and finding a high association between ideology and outcome); Harold J. Spaeth, Judicial Power as a Variable Motivating Supreme Court Behavior, 6 MidWEST J. PoL. ScI. 54 (1962) (analyzing Warren Court decisions and finding that federalism was less important in determining the outcome of the case than was ideology or activism).

201. Lessig, supra note 164, at 193.

202. United States v. Lopez, 514 U.S. 549, 588 (1995) (Kennedy, J., concurring); see also United States v. Hickman, 179 F.3d 230, 242 (5th Cir. 1999) (Higginbotham, J., dissenting) (noting that "we do no more today than insist that Congress identify a non-pretexual, rational basis ...").

203. United States v. Morrison, 529 U.S. 598, 643 (2000) (Souter, J., dissenting).

204. Even economic regulations express our preference for capitalism, and redistributive programs express our interest in compassion.

205. This of course is what distinguishes criminal from civil law. See, e.g., Susan R. Klein, Redrawing the Criminal-Civil Boundary, 2 BuFf. CRIM. L. Rev. 679, 685-86 (1999) (outlining the modem American paradigm of criminal law-a legislative purpose to punish a person for committing a morally culpable act that injures society); Carol S. Steiker, Punishment and Procedure: Punishment 
addition to forcing the federal government out of criminal law entirely, and reversing numerous Supreme Court cases, ${ }^{206}$ a motive test is not feasible. Even if it were possible to determine the "intent" of a multimember body like Congress, it would become adept at mouthing the right words and hidmg its motive, and any Court attempt to pierce the pretext would be entirely speculative. ${ }^{207}$

Finally, a body of literature has suggested the Court adopt "process federalism" rather than substantive federalism. These process-based federalism schemes all focus on the process by which Congress enacted the legislation; each asks whether there is a sufficient written congressional record supporting the economic effect of the activity regulated. ${ }^{208}$ This is a perfectly plausible method for ensuring decentralization federalism, perhaps preferable to the Court's current substantive rational-basis-plus test. My own discussion in Part I.B of institutions and doctrines in the criminal law (such as the dearth of private causes of action, the lack of preemption, and the meager size of the federal law-enforcement apparatus relative to the states) that currently ensure decentralization and experimentation without Court intervention is a strong form of process federalism. The structure of the federal criminal law-enforcement apparatus accomplishes this without any Court test. However, a "process federalism" test will provide insufficient protection for minority norms, which will certainly be defeated in the process. Thus Hawaii and Vermont could not defeat the federally imposed DOMA, and California could not convince Congress to reschedule marijuana. ${ }^{209}$ If we wish to protect minority norms confined to a single state, a substantive bright-line Court-imposed federalism test is required. The

Theory and the Criminal-Civil Procedural Divide, 85 GEo. L.J. 775, 797-806 (1997) (suggesting that a sanction must be labeled criminal rather than civil if its purpose is to punish immoral behavior).

206. See, e.g., Scarborough v. United States, 431 U.S. 563 (1977) (banning transportation of guns for felons); Champion v. Ames, 188 U.S. 321, 363-64 (1903) (upholding legislation banning the transportation of lottery tickets).

207. See, e.g., King \& Klein, supra note 80, at 1540-42 (rejecting legislative purpose as one of the factors the Court should use to police legislative evasion-of-the-elements rule set out in Apprendi $v$. New Jersey, and collecting literature and caselaw reviling purpose analysis as "indeterminate, illogical, and futile"); but see Mitchell Berman, Coercion Without Baselines: Unconstitutional Conditions in Three Dimensions, 90 GEO. L.J. 1 (2001) (recommending motive test).

208. See, e.g., Barry Friedman, Legislative Findings and Judicial Signals: A Positive Political Reading of United States v. Lopez, 46 CASE W. RES. L. REv. 757 (1996) (suggesting that Congress must establish a record justifying national legislation to withstand Court scrutiny); Stephen Gardbaum, Rethinking Constitutional Federalism, 74 TEx. L. Rev. 795 (1996) (suggesting that the Court should review the congressional record to determine whether Congress took federalism concerns into account and justified federal legislation, analogizing his test to the "hard look" doctrine of judicial review of administrative decisions); Jackson, supra note 192, at 2181 (proposing a "process-based "clear evidence/clear statement" test, under which Congress must produce a record, consisting of legislative hearings and floor debate, detailing why the exercise of authority was appropriate); Lessig, supra note 164, at 207-13 (suggesting the Court require procedures such as a clear statement of economic effect, a review of any self-inposed limits Congress built into the statute, and whether the legislation allows states to opt out).

209. See supra notes 100-110. 
Court's current Commerce Clause jurisprudence may be as close as we can come.

\section{III \\ INDEPENDENT-NORM EXAMPLES}

The Court's new limitations on federal authority under the Commerce Clause should provide a narrow range of protection for independent norms in criminal law, and little protection against concurrent federal-state criminal jurisdiction. Whenever the conduct to be regulated, whether economic or purely moral, physically crosses a state line, it can be regulated pursuant to the channels or instrumentalities tests, and it will be reviewed under a rational-basis test. Where the conduct is wholly intrastate but commercial, it can be regulated pursuant to the substantial-effects test, though with slightly more stringent review. Only where the conduct is wholly intrastate, of a noneconomic nature, and will have little or no economic-spillover effect on neighboring states, is there any hope for Court protection. Very few areas of conduct fit into this narrow category. Regulation of certain sexual, religious, educational, and medical practices may be circumscribed, at least where federal and state regulation is not already prohibited by the First Amendment or substantive due process' privacy penumbra.

A look at three issues presently percolating through our courts and state and federal political systems will be instructive on the issue of whether the Court's current Commerce Clause jurisprudence will protect any independent norms, as I suggest it should, or whether politics will triumph over neutral application of the law, as is entirely possible. I will discuss the states' regulation of sodomy and gay marriages and two medical regulations-the use of life-ending drugs by the terminally ill and the use of medicinal marijuana. These three examples fit into the small class of policy disputes where the disagreement is primarily moral rather than economic or commercial, and the effects of an outlier policy in an outlier state can be substantially confined to that state. This combination is an attractive case for federalism. Because the disagreement is moral, the case for diversity is very strong, and concomitantly the case for Commerce Clause regulation is very weak. Though, admittedly, my version of the Court's current Commerce Clause test has to strain a bit to fit these three examples, the kinds of cases warrant judicial protection.

\section{A. Same-Sex Marriages}

Homosexuals are presently free from the risk of federal criminal prosecution for sodomy, regardless of whether or not they are married, only if they remain in or travel to those states where sodomy is legal. The Mann Act originally barred the transportation in interstate or foreigu commerce of any woman or girl with the intent that she engage in 
prostitution or for any other immoral purpose. ${ }^{210}$ This rather vague federal prohibition of interstate movement for the purpose of "immoral" conduct was upheld in a series of Supreme Court cases. ${ }^{211}$ Nevertheless, the statute was amended in 1986 to change "immoral purpose" to "any sexual activity for which any person can be charged with a criminal offense," and the gender-specific language was removed. ${ }^{212}$ It thus appears that, in light of Bowers v. Hardwick ${ }^{213}$ and the many states, such as my home state of Texas, that still criminalize sodomy, ${ }^{214}$ same-sex couples validly married in Hawaii cannot vacation in Texas, so long as their intent to engage in sex is "one of the dommant purposes" of their trip. ${ }^{215}$ Though there is some small chance that the Court would protect sodomy between homosexual couples validly married in their home state, ${ }^{216}$ and there is little chance that the U.S. Attorney's office would actually prosecute such a case, ${ }^{217}$ thcre remains some small risk of federal prosecution. ${ }^{218}$ This slight risk, coupled with the attendant social consequences of engaging in even unenforced criminal behavior, ${ }^{219}$ may be sufficient to chill the behavior.

210. See U.S. Dep't of Commerce \& Labor, Ann. Rep. Secretary (1908); S. Doc. No. 196, 51st Cong., 2d Sess. (1909); 45 Cong. Rec. 813, 1036-37 (1910).

211. See Caminetti v. United States, 242 U.S. 470 (1917) (upholding conviction for transportation of a wounan from California to Nevada for purpose of consensual sex, rejecting challenge that the statute was intended to criminalize only commercial vice); Hoke v. United States, 227 U.S. 308 (1913) (upholding constitutionality of the Mann Act against Commerce Clause and right-to-travel challenges); Note, Interstate Immorality: The Mann Act and the Supreme Court, 56 YALE L.J. 718 (1947) (criticizing Supreme Court interpretation of "immoral purpose" language of Mann Act as vague and contrary to the rule of lenity).

212. See 18 U.S.C. $\$ 2421$ (2000) (codified as amended by Pub. L. No. 99-628, 100 Stat. 3510 (1986)).

213. 478 U.S. 186 (1986) (due process does not prevent the criminalization of consensual sodomy by gay partners).

214. Tex. Penal Code ANN. $\S 21.06$ (Vernon 1994); Diana Hassel, The Use of Criminal Sodomy Laws in Civil Litigation, 79 TEx. L. REv. 813, 821 n.46 (noting the sixteen states that currently criminalize sodomy and that four of those limit the ban to persons of the same sex).

215. See, e.g., Mortensen v. United States, 322 U.S. 369, 374 (1944) (interpreting the Mann Act to require that the defendant's intent that girl engage in prostitution "must be fonnd to exist before the conclusion of the interstate journey and must be the dommant motive of such interstate movenient"); United States v. Miller, 148 F.3d. 207 (2d Cir. 1998); United States v. Snow, 507 F.2d 22 (7th Cir. 1974).

216. This seems to ne quite unlikely. Even if the Court were willing to recognize homosexual marriages in the state in which they were performed, it still might allow federal prosecution in a state where such marriage was not recognized under the DOMA, supra note 17 , and where sodomy is a crime.

217. U.S. ATT'Ys MANUAL $\$ 9-79.100$ (1997) (providing that nnless minors are the victims, prosecution should be limited to "persons engaged in comınercial prostitution activities").

218. See, e.g., Cleveland v. United States, 329 U.S. 14 (1946) (rejecting freedom of religion challenge to Mann Act conviction of Mormon husbands for transportation of their plural wives across state lines, and finding polygamy was "immoral" within the meaning of the Act); Lawrence v. State, 41 S.W.3d 349 (Tex. Ct. App. 2001) (upholding the convictions of two men for consensual sodomy in violation of section 21.06 of the Texas Penal Code).

219. See, e.g., Ryan Goodman, Beyond the Enforcement Principle: Sodomy Laws, Social Norms, and the Social Panoptics, 89 CALIF. L. REv. 643 (2001) (examining social effects of underenforced 
Neutral application of current Commerce Clause jurisprudence should mean that this risk is eliminated, and the minority norm is protected, so long as the individual remains in her home state (and the state protects the norm). Though homosexual sodomy is not protected from state or federal criminalization by the privacy penumbra that shelters procreation and pregnancy-termination decisions, ${ }^{220}$ Congress has no authority to regulate purely intrastate sexual behavior of a noncommercial nature. ${ }^{221}$ Thus, while current Commerce Clause jurisprudence allows the current Mann Act to stand, it should prevent Congress from adopting a "mega-DOMA" prohibiting individual states from recognizing same-sex marriages, and should likewise prevent Congress from enacting a federal ban on sodomy similar to the Mann Act but without the requirement of interstate movement in furtherance of sodomy.

\section{B. Physician-Assisted Suicide}

Can the federal government prevent terminally ill Oregonians from ending their lives? This is another area to which the Due Process Clause of the Fourteenth Amendment does not speak-it neither mandates nor prohibits assisted suicide. ${ }^{222}$ Oregon's voters have twice approved an assistedsuicide statute, permitting doctors to prescribe lethal medications to competent terminally ill Oregonian adults. ${ }^{223}$ Republican Attorney General John Ashcroft, reversing a 1998 administrative decision by former Democratic Attorney General Janet Reno, ${ }^{224}$ determined that "prescribing... controlled substances to assist suicide violates the Controlled Substances Act" and has asked the DEA to revoke the drug licenses of doctors who prescribe life-ending medication pursuant to the

sodomy laws in South Africa); Hassel, supra note 214 (detailing use of underenforced sodomy laws to disadvantage gay people in family law, public employment, and immigration).

220. Bowers v. Hardwick, 478 U.S. 186 (1986).

221. Perhaps one could argue that sodomy can be federally prohibited so long as the statute requires movement across state lines by either party at any time, for any reason. This in essence imprisons homosexuals forever in their home states. 1 would hope that this would be an unconstitutional status crime or would violate the right to travel. See, e.g., Robinson v. California, 370 U.S. 660 (1962); Lambert v. California, 355 U.S. 225 (1957). Admittedly, such a holding would cast some doubt on the objectiveness of the bright-line test permitting federal regulation whenever there is interstate movement. However, a limit on federal regulation that excludes persons, unless those persons were moving in furtherance of the crime, would still be manageable.

222. See Vacco v. Quill, 521 U.S. 793 (1997) (holding that state bans on assisted suicide do not violate the fourteenth amendment); Washington v. Glucksberg, 521 U.S. 702 (1997) (same).

223. Oregon's Death With Dignity Act was approved in 1994 and 1997. Or. REv. STAT. $\S \S 127.800-127.880$ (2001). Physicians can assist patient suicide after two doctors certify that the patient has less than six months to live, has voluntarily chosen to die, and is competent to make healthrelated decisions.

224. Letter from the Honorable Janet Reno, Attorney General of the United States, to Chairman Henry J. Hyde, House Comm. on the Judiciary (June 5, 1998), available at http://www.usdoj.gov' opa/pr/1998/June/259ag.htm.html. 
Oregon Act. ${ }^{225}$ General Ashcroft's actions were first temporarily stayed and then permanently enjoined by a conservative republican federal judge appointed by President Bush's father. ${ }^{226}$ Though the opinion was rendered purely as a matter of statutory interpretation, ${ }^{227}$ the indignation and constitutional challenge rang clear:

On November 6, 2001, with no advance warning to Oregon representatives, Attorney General Ashcroft ... fired the first shot in the battle between the state of Oregon and the federal government over which government has the ultimate authority to decide what constitutes the legitimate practice of medicine ... the citizens of Oregon, through their democratic initiative process, have chosen to resolve the moral, legal, and ethical debate on physician-assisted suicide for themselves by voting-not once, but twice-in favor of the Oregon Act. ${ }^{228}$

While the constitutional question is a close one, neither criminal prosecution nor civil penalties against Oregon doctors should survive Commerce Clause scrutiny. The Solicitor General's Office would argue that being paid by a patient to write a prescription is a commercial activity, and that, in the aggregate, this purely intrastate activity substantially affects interstate commerce. However, one would be hard pressed to define this effect as substantial, given that the Act has authorized prescriptions for no more than ninety-one terminally ill people since 1997.229 Doctors and state officials could make their case more attractive by writing their prescription for free or even providing the drug from a state-run dispensary.

A better way for the federal government to justify Attorney General Ashcroft's action, or any new federal legislation criminalizing the writing

225. See Dispensing of Controlled Substances to Assist Suicide: Att'y Gen. Order No. 2534-2001, 66 Fed. Reg. 56,608 (Nov. 9, 2001).

226. Oregon v. Ashcroft, Temporary Restraining Order, Case No. CV01-1647 (D. Or. 2001), permanent injunction imposed in Oregon v. Ashcroft, 192 F. Supp. 2d 1077 (D. Or. 2002). U.S. District Judge Robert E. Jones was appointed by former president Bush in 1990.

227. Oregon v. Ashcroft, 192 F. Supp. 2d at 1088 (holding that when Congress enacted the federal Controlled Substances Act and implementing regulations, which permits the DEA to revoke the registration of physicians and pharmacists who prescribe a controlled substance other than for "a legitimate medical purpose," it intended that each state, not the Attorney General, determine what medical practices are "legitimate").

228. Id. at 1078-79. Judge Jones noted that officials from Oregon specifically asked Attorney General Ashcroft, in writing, to consult them if former General Reno's interpretation of the Controlled Substances Act were to be reexamined. Though General Ashcroft's office assured Oregon representatives that no change was anticipated, and that the Department of Justice would consult with them if the situation changed, "the Attomey General of the United States completely iguored his earlier promise to the Oregon Attorney General to ascertain Oregon's views." Id. at 1083.

229. There is some dispute as to the precise number. See id. at 1082 ("Since 1997, the Oregon Act has been utilized by approximately 70 terminally ill Oregonians."); Carol M. Ostram, Mom's Assisted Suicide Places a Face on Debate, Hous. Chron., Mar. 3, 2002, at A49 (counting 91 prescriptions since 1997). 
of such prescriptions ${ }^{230}$ is to claim that regulating the writing of prescriptions for lethal doses of barbiturates is "an essential part of a larger regulation of economic activity, in which the regulatory scheme could be undercut unless the intrastate activity were regulated."231 The constitutionality of the regulation of a few prescriptions written in Oregon will depend on how the Court defines the term "essential." Certainly, the regulation of prescription drugs nationwide will be upheld, either because the drugs themselves travel through commerce or because the sale of drugs is a commercial activity substantially affecting interstate commerce. Time will tell whether the regulation of those ninety-one prescriptions, certainly less than a fraction of $1 \%$ of the total number written in any given year, are an essential part of the federal government's scheme to regulate drug sales nationwide, or whether the Court will see fit to unbundle a particular drug in a particular state from the comprehensive scheme. A neutral application of the law points to the latter result.

Should the Court side with Ashcroft, officials in Oregon could nonetheless escape federal regulation by authorizing the use of less-powerful drugs not regulated by the DEA or authorizing less-pleasant methods such as gunshots or asphyxiation. If the Court neutrally and strictly enforces its new Commerce Clause jurisprudence, it ought to put this medical care decision on the noncommercial side of the line and subject the regulation to more stringent review. The effect on commerce of these few prescriptions should be deemed nonessential to the regulatory scheme and too attenuated to justify federal intervention. ${ }^{232}$

\section{Medicinal Marijuana}

In the final and most difficult example, I will consider whether the federal government can defeat the Compassionate Use Acts enacted in nine states. ${ }^{233}$ The Court specifically declined to address this issue in United

230. "Between 1998 and 2000, two separate federal legislative attempts to preempt the Oregon act have failed to pass." Oregon v. Ashcroft, 192 F. Supp. $2 \mathrm{~d}$ at 1083.

231. United States v. Lopez, 514 U.S. 549, 561 (1995); see also Hodell v. Indiana, 452 U.S. 314, $329 \mathrm{n} .17$ (1981) (holding that provision not valid in itself may be upheld if it is "an integral part of [a] regulatory program"); Adrian Vermuele, Does Commerce Clause Review Have Perverse Effects?, 46 VILL. L. Rev. 1325 (2001) (arguing that current Commerce Clause doctrine will have the perverse effect of increasing centralization because Congress will enact very broad and comprehensive regulatory schemes to ensure that regulation of intrastate behavior will be deemed constitutional).

232. The government might argue, as it did in Lopez, that the effect on commerce is not simply the few dollars spent on the doctor visit and the pill, but includes additional effects such as lost wages and funeral expenses. Such effects were rejected as too attenuated in Lopez, however, and they are even more of a stretch in this case.

233. See Compassionate Use Act of 1996, Cal. Health \& SAfETy Code $§ 11362.5$ (West Supp. 2000); Ariz. Rev. Stat. AnN. § 13-3412.01 (West 1997); Alaska Stat. AnN. § 11.71.090, 17.37.010-17.37.080 (Michie 2000); Nev. Sec'y of State, Gen. Election Ballot Question 9-1998, available at http://sos.state.nv.us/nvelection/1998general/questions/29.html (supporting amendment to state constitution allowing medieinal use of marijuana); NEv. Const. art. 4, $\S 38$; Oregon Medical 
States v. Oakland Cannabis Buyers' Cooperative, where it upheld a civil injunction against a marijuana cooperative and rejected the argument that the injunction had to be modified to recognize a common-law medicalnecessity defense. ${ }^{234}$ Though rightly holding that the defense of legal necessity can never succeed where a legislature itself has determined that it should not, the Court noted that it would not "consider the underlying constitutional issues," including whether the federal drug statutes "exceed Congress' Commerce Clause powers." ${ }^{235}$ The three concurring Justices, led by champion-of-federalism Justice Stevens, noted that the majority's holding that there is no necessity defense applies only to distribution cases. ${ }^{236}$ Justice Stevens stated that we ought to show "respect for the sovereign States that comprise our Federal Union"237 by allowing a necessity defense to federal prosecutions where the individual merely cultivated and possessed marijuana based upon his physicians' recommendations.

I will here posit the most attractive case for the state of California: cultivation of marijuana by patients themselves, after receiving a letter from their doctor verifying that they have one of the listed diseases and that no other course of treatment was effective, and after receiving the seeds directly from city officials. ${ }^{238}$ This scenario, which excludes all economic transactions, is not farfetched. ${ }^{239}$

Marijuana Act (allowing citizens "suffering from debilitating medical conditions" to use "small amounts"); OR. REv. STAT. \$ $\$ 475.300-475.346$ (1999); Measure No. 692 (allowing "qualified patients" to use marijuana); WASH. REv. CODE ANN. \$§ 69.51A.005-900-69.51A.902 (1997) \& Supp. 2000-01 (West Supp. 2001); Colorado Amendment 20, CoLo. Const. art. XVIIl, § 14 (allowing medical use of marijuana and creating a state-run confidential registry); ME. Rev. STAT. ANN. tit. 22, § 2383-B(5) (2000); Legalization of Marijuana for Medical Treatment lnitiative of 1998, (approved by D.C. voters); Halv. REv. STAT. \$ 329-121a to -128 (Supp. 2000).

234. 532 U.S. 483 (2001).

235. Id. at 494 (holding that because there is no statutory ainbiguity, the canon of constitutional avoidance has no application).

236. Id. at 502 (Stevens, J., joined by Souter, J., and Ginsburg, J., concurring). The concurrence criticizes the majority for a broader hoiding that the defense of necessity is unavailable to anyone under the Controlled Substance Act.

237. Id.

238. If the state were to limit Proposition 215 in this manner, patients and government officials would be subject to, at most, a federal misdemeanor offense for their first conviction. See 21 U.S.C. $\$ \$ 841(b)(4), 844(2000)$.

239. Proposition 215 authorizes only the possession and cultivation of marijuana after approval by a physician. Compassionate Use Act of 1996, Cal. Health \& Safety Code $\$ 11362.5$ (d) (West Supp. 2000). The District Attorney of San Francisco, in an amicus brief filed at the lower-court level, indicated that San Francisco may authorize city health officials "to operate marijuana distribution centers for seriously ill patients." Brief of Amicus Curiae District Attorney of San Francisco at 11, United States v. Cannabis Cultivators Club, 5 F. Supp. 2d 1086 (N.D. Cal. 1998). The City of San Jose presently licenses dispensaries to control the strength and number of marijuana plants and to set maximum client purchases per week. Dan Baum, California Separate Peace, Rolling Stone Mag., Oct. 30, 1997, at 43; Elaine Shannon, Too High in California?, Time, Dec. 8, 1997, at 84. The Oakland Police Department licenses a single cooperative and requires patients to carry identification cards. Michael Pollan, Living with Medical Marijuana, N.Y. Times MAG., July 20, 1997, at 2-23. 
In resolving the Commerce Clause issue, the Court would have to ask whether this purely intrastate behavior, in the aggregate, substantially affected commerce. It seems to me the answer might well be "no," depending upon how the class of activity being regulated is defined and whether one believes that users of medicinal marijuana are otherwise law abiding. If the class of activity being regulated is the entire illegal-marijuana market, or even the entire illicit-drug market, then of course in the aggregate the transactions have a substantial effect on commerce or would be an essential part of the larger regulatory scheme. However, one could argue that the class is the purely in-state legal medicinal marijuana growers and users, and that there is no national market for this class of activity. Likewise, one could argue that the federal regulatory scheme concerns only the national market for illegal marijuana, not the local market for the distinguishable medicinal marijuana. ${ }^{240}$ If a seriously ill patient in California is denied legal medicinal marijuana by contrary federal law, he will simply suffer rather than attempt to obtain marijuana through the illegal drug market. Thus, preventing California from adopting its independent norm will have no effect on interstate commerce. This distinguishes this scenario from the Wickard case, because if Mr. Wickard was barred from home-growing his wheat, he certainly would have purchased it on the legal national market.

An outlier state would also have to convince the Court that those states allowing medicinal marijuana regulate it stringently enough to prevent it from finding its way onto the national black market. ${ }^{241}$ Were the legal medicinal marijuana to escape local control, the effect on interstate commerce would be substantial. Finally, the outcome would depend on whether the Court views medicinal marijuana as part of the clearly commercial national war on drugs, or as part of the traditionally state-regulated realm of those medical care decisions made by individuals in consultation with their doctors.

\section{CONCLUSION}

The distinction between decentralization and independent-norm federalism in criminal law is a useful one, regardless of whether its purpose is purely descriptive or doctrinal. As a descriptive matter, it identifies those federal criminal statutes that contradict independent state norms and therefore are most likely to impinge upon the states as protectors of individual liberties. It also relieves those scholars, legislators, and judges concerned

240. This distinction between the legal- and illegal-drug markets was made by Lauryn P. Gouldin in Cannabis, Compassionate Use and the Commerce Clause: Why Developments in California May Limit the Constitutional Reach of the Federal Drug Laws, 1999 ANn. Surv. AM. L. 471, 518-19 (1999).

241. Perhaps, in our day of biological engineering, we could develop a local strain of marijuana that is different in appearance in order to test whether it is escaping local control. 
that states remain laboratories for achieving shared norms from concern regarding federal criminal statutes that merely replicate state norms. Unique attributes of criminal law, such as the minor role played by the federal government, the lack of private causes of action, and the failure of federal law to preempt state law, lead to a robust level of experimentation in cases involving shared norms, regardless of Court intervention. As a prescriptive matter, assuming the desirability of independent norms, the distinction might be used as a basis for applying heightened judicial scrutiny only to this category of cases, for adding the protection of independent state norms as a factor in the Lopez rational-basis-plus test for federal statutes that affect interstate cominerce, and as an argument in favor of retaining the present objective channels and instrumentalities tests that focus on physical and economic spillover into a neighboring state.

1 have suggested that the Court is already moving toward an objective economic- and physical-spillover test for federal civil and criminal statutes enacted pursuant to the Cominerce Clause, regardless of whether these statutes implicate decentralization federalism or independent-norm federalism. In the context of criminal law, statutes that provide concurrent federal jurisdiction over misconduct already illegal pursuant to state law do no real harm to either the decentralization or liberty-enhancing values of federalism. While a judicial finding of unconstitutionality here wastes time and energy, it likewise does little harm, as the prohibition can be reenacted with a jurisdictional hook, achieved through the Spending Clause, or enforced at the state level. Where the federal statute restricts state-created liberties, however, it harms the decentralization and liberty-enhancing values of federalism, and a judicial finding of unconstitutionality under the Commerce Clause has real bite in protecting these values.

It is these very few cases that warrant judicial and scholarly attention. One might legitimately be leery of constructing doctrinal distinctions based on institutional features and doctrines that distinguish criminal from civil law, when such distinctions are not grounded in the text or history of the Constitution. However, one cannot legitimately argue in favor of protecting federalism where the federal statute harms business interest, but not where it harms homosexuals. Though my three examples in Part III all concerned "liberal" issues, a neutrally applied federalism test should, of course, protect moral and political minorities, on both the Left and the Right, who cluster in communities and control a state's policy, on any issue not subject to a guarantee of rights secured by the United States Constitution. To remain viable, the Court's new federalism must at least appear to be neutrally apphed. 
